Research Article

\title{
Combined Application of Coagulation/Flocculation/ Sedimentation and Membrane Separation for the Treatment of Laundry Wastewater
}

\author{
Camila O. C. Nascimento ${ }^{D},{ }^{1}$ Márcia T. Veit, ${ }^{1}$ Soraya M. Palácio, ${ }^{1}$ Gilberto C. Gonçalves, ${ }^{2}$ \\ and Márcia R. Fagundes-Klen (iD) ${ }^{1}$ \\ ${ }^{1}$ Department of Chemical Engineering, Western Paraná State University-UNIOESTE, Campus of Toledo, Rua da Faculdade 645, \\ Jd. Santa Maria, 85903-000 Toledo, PR, Brazil \\ ${ }^{2}$ Federal Technological University of Paraná-UTFPR, Rua Cristo Rei 19, Vila Becker, 87020-900 Toledo, PR, Brazil
}

Correspondence should be addressed to Camila O. C. Nascimento; camilacardo01@hotmail.com

Received 24 November 2018; Revised 11 February 2019; Accepted 14 February 2019; Published 7 March 2019

Academic Editor: Antonio Brasiello

Copyright (C) 2019 Camila O. C. Nascimento et al. This is an open access article distributed under the Creative Commons Attribution License, which permits unrestricted use, distribution, and reproduction in any medium, provided the original work is properly cited.

\begin{abstract}
The wastewater from industrial laundries has a high quantity of contaminants from the washing process, as well as chemical additives. Aiming at the treatment of this type of wastewater, the present study evaluated the performance of a combined coagulation/ flocculation/sedimentation process $(\mathrm{C} / \mathrm{F} / \mathrm{S})$ and membrane separation to treat laundry wastewater in relation to physicochemical parameters of water quality. For this purpose, a Doehlert experimental design was applied to the C/F/S step using the natural coagulant Tanfloc $\mathrm{POP}{ }^{\circledR}$ with maximum color and turbidity removal efficiency obtained of $80.27 \%$ and $86.50 \%$, respectively, under conditions of $\mathrm{pH}$ of 6.4 and a coagulant concentration of $110 \mathrm{mg} \cdot \mathrm{L}^{-1}$. The supernatant from the $\mathrm{C} / \mathrm{F} / \mathrm{S}$ step was used in the sequential microfiltration (MF) and ultrafiltration (UF) experiments. The maximum values of color, total nitrogen, dissolved solids, and turbidity removal were similar to MF and UF membranes at transmembrane pressure of 1.4 bar, with the greatest flow of permeates $\left(92.2 \mathrm{~L} \cdot \mathrm{h}^{-1} \cdot \mathrm{m}^{-2}\right)$ presented by the MF membrane at $1.4 \mathrm{bar}$. The total efficiency of the combined C/F/S-MF process indicated the quality of the treated wastewater since it reduced $98.4 \%$ of the color, $99.1 \%$ of turbidity, $71.7 \%$ of the surfactants, and more than $55 \%$ of the total dissolved solids (TDS), chemical oxygen demand (COD), and total organic carbon (TOC) from the industrial laundry wastewater. This study showed that the $\mathrm{C} / \mathrm{F} / \mathrm{S}-\mathrm{MF}$ combined process could be an efficient treatment of laundry wastewater.
\end{abstract}

\section{Introduction}

In the industrial activities, water consumption is usually high, resulting in a large volume of wastewater that must be treated before the release into the water systems. Such wastewater, if untreated or inadequately treated, might pose risks to the aquatic environment since the molecules of the contaminants may have carcinogenic and mutagenic properties or lead to mutagenic actions in the living beings present in the medium [1].

The wastewater from industrial laundries has in its composition different levels of suspended solids, turbidity, COD, salts, and nutrients [2] due to the presence of dirt and residues from detergents and softeners that are used during the washing process [3]. The main chemical additive found in this class of wastewater is the detergent, which has surfactants as one of the main constituents that assist in the removal of dirt related to food debris, body residues, and the environment from the fabric [4].

The methods applied to efficiently treat the wastewater from industrial laundries are usually based on the combination of biological, physical, and chemical processes such as electrocoagulation $[5,6]$, membrane separation processes [7-10], membrane bioreactors [11], adsorption [12], photolysis [13], electrocoagulation/electroflotation [14], coagulation [15], coagulation/membranes [16-18], and coagulation/adsorption [19]. 
Among the used methods, the $\mathrm{C} / \mathrm{F} / \mathrm{S}$ process has been highlighted due to the high efficiency in removing the organic matter and its low operating cost. Moreover, there is a great variety of natural or inorganic coagulants available for treating wastewater $[13,20]$.

The inorganic coagulants present some advantages regarding the efficiency of turbidity removal and their large availability [21]. Nevertheless, they show many disadvantages such as the low level of biodegradability and toxicity, posing a risk to the human health [22]. Toxic effects from several substances in the water and wastewater might be evaluated according to ecotoxicity tests using microorganisms, plants, fish, and invertebrates [23].

The aluminum sulfate inorganic coagulant is widely used in water treatment [24], and its presence after the process, even in residual amounts, has been linked to the accumulation of aluminum salts in the human body, leading to disorders such as anemia, Alzheimer's disease, loss of memory, and headaches $[25,26]$.

Due to the disadvantages of the use of inorganic coagulants (aluminum and iron salts), a promising alternative is the use of natural coagulants extracted from biological materials (seeds and shells) that are usually nontoxic [21], renewable, and biodegradable, presenting a great efficiency when removing turbidity [26], surfactants, and dyes from industrial wastewater [15].

In general, the conventional wastewater treatment processes usually result in an incomplete removal of toxins, microorganisms, and other contaminants present in the wastewater. This fact has been stimulating studies that apply membrane separation processes (MSP) to obtain a superior quality of the treated water [27-29].

The MSP present some advantages over conventional processes such as a high standard performance, reduction of the environmental impact caused by the wastewater, and the compliance regarding the environmental regulations for the discharge of wastewater into the water bodies [7].

In this context, the use of natural coagulant in $\mathrm{C} / \mathrm{F} / \mathrm{S}$ step combined with MSP in sequence has been providing an interesting alternative to obtain treated water with a higher quality. When applying the $\mathrm{C} / \mathrm{F} / \mathrm{S}$ process as a primary treatment, there is a removal of bigger particles and organic matter and, consequently, a reduction of fouling on the membrane, increasing the total efficiency of the process [29].

The Doehlert experimental design is applied to optimized variables and has been highlighted in applications to optimized variables in different methods [30-37]. This design is more efficient than others like Box-Behnken and central composite designs because the advantages of selecting the order of variables can be large or small number of levels, requiring fewer experiments and be more efficient $[38,39]$.

Thus, the objective of this study was to evaluate the total efficiency of the combined C/F/S-MSP regarding the physicochemical parameters of the laundry wastewater using the optimized $\mathrm{pH}$ and coagulant concentration obtained from the optimized conditions of Doehlert experimental design, membrane type, and transmembrane pressure conditions.

\section{Materials and Methods}

2.1. Wastewater and Analytical Determinations. The wastewater was collected from the equalization tank, which receives and stores all the water used in the washing step, at an industrial laundry located in the west of Paraná, Brazil. The wastewater was stored in polyethylene tanks with a capacity of 20 liters and kept refrigerated.

Three collections were carried out on different days with different destinations: batch 1 was used for the C/F/S assays to determine the optimum $\mathrm{pH}$ value and coagulant concentration; batch 2 was employed in the combined C/F/S and membrane separation (MF and UF) processes to determine the best transmembrane pressure; and batch 3 was used in the experiments for the best experimental conditions obtained in the two previous steps for the selected membrane.

The characterization of the wastewater (batch 1,2 , and 3 ), the supernatant collected in the best condition of the $\mathrm{C} / \mathrm{F} /$ $\mathrm{S}$ step, and the permeate obtained from the combined C/F/SMF process followed the procedures described in Table 1. The assays were performed in duplicate. The analyses of residual chlorine and thermotolerant coliforms were carried out only for the permeate collected in the best experimental condition of the $\mathrm{C} / \mathrm{F} / \mathrm{S}-\mathrm{MF}$ process. Toxicity assays using the lyophilized Vibrio fischeri bacteria (BIOLUX ${ }^{\circledR}$ LYO5, Umwelt) were performed for the wastewater sample and for the permeate obtained from the combined process $(\mathrm{C} / \mathrm{F} / \mathrm{S}$ $\mathrm{MF}$ ) in the best experimental condition.

2.2. Evaluation of $C / F / S$ Parameters. For the $C / F / S$ step, it was used the natural coagulant Tanfloc $\mathrm{POP}^{\circledR}$ produced from the black wattle bark (Acacia mearnsii De Wild) and provided by TANAC S.A.

The Doehlert experimental design for the C/F/S assays (batch 1) was applied for two variables ( $\mathrm{pH}$ and coagulant concentration) to determine the experimental condition with higher efficiency in the removal of color and turbidity. For the coagulant concentration and $\mathrm{pH}$, three $(60,120$, and $\left.180 \mathrm{mg} \cdot \mathrm{L}^{-1}\right)$ and five levels $(4.6,5.5,6.3,7.2$, and 8.0) were tested, respectively. All the assays were performed in duplicate.

The experiments were performed in a jar test (JT102Milan) containing one liter of the wastewater in each tank with different concentrations of coagulant $\left(\mathrm{mg} \mathrm{L}^{-1}\right)$ with two stirring periods (based on preliminary tests): one at $120 \mathrm{rpm}$ for 2 minutes and another one at $20 \mathrm{rpm}$ for 2 minutes, followed by 10 minutes of settling. Blank experiments were also performed (without adding the coagulant). The $\mathrm{pH}$ of the wastewater was adjusted according to the value determined from the experimental design by adding $\mathrm{NaOH}$ $1 \mathrm{~mol} \cdot \mathrm{L}^{-1}$ and $\mathrm{HCl} 0.1 \mathrm{~mol} \cdot \mathrm{L}^{-1}$ solutions, meeting the $\mathrm{pH}$ range required by the coagulants (4.5-8) [45]. The assays were carried out in duplicate and at room temperature $\left(25^{\circ} \mathrm{C}\right)$. The collected samples of supernatant were evaluated regarding the removal of color and turbidity and determining the $\mathrm{pH}$ as well.

Experiments complementary to the design were also performed at a $\mathrm{pH}$ value of 6.4 and coagulant concentrations of $100,110,120$, and $130 \mathrm{mg} \cdot \mathrm{L}^{-1}$. It was conducted to 
TABle 1: Physicochemical parameters evaluated for the characterization of the laundry wastewater, determination methods, and analytical protocols.

\begin{tabular}{|c|c|c|}
\hline Parameter & Unit & Procedure \\
\hline $\begin{array}{l}\text { Total organic } \\
\text { carbon (TOC) }\end{array}$ & $\mathrm{mgCL}^{-1}$ & $5310 \mathrm{C}[40]$ \\
\hline Free residual chlorine & $\mathrm{mg} \mathrm{L}^{-1}$ & $4500-\mathrm{Cl} \mathrm{A} \mathrm{e} \mathrm{G} \mathrm{[41]}$ \\
\hline $\begin{array}{l}\text { Thermotolerant } \\
\text { coliforms }\end{array}$ & $\mathrm{NMP} / 100 \mathrm{~mL}$ & ISO 9308-1:2014 [42] \\
\hline Conductivity & $\mu \mathrm{S} \mathrm{cm}^{-1}$ & 2510B [40] \\
\hline Apparent color & $\mathrm{mg}_{\mathrm{Pt}-\mathrm{Co}} \mathrm{L}^{-1}$ & $8025[40]$ \\
\hline $\begin{array}{l}\text { Biochemical oxygen } \\
\text { demand (BOD) }\end{array}$ & $\mathrm{mg} \mathrm{O}_{2} \mathrm{~L}^{-1}$ & 5210 A e B [41] \\
\hline $\begin{array}{l}\text { Chemical oxygen } \\
\text { demand (COD) }\end{array}$ & $\mathrm{mg} \mathrm{O}_{2} \mathrm{~L}^{-1}$ & $5220 \mathrm{D}[40]$ \\
\hline Total nitrogen & $\mathrm{mg} \mathrm{L}^{-1}$ & D5176 [43] \\
\hline $\mathrm{pH}$ & & $4500-\mathrm{H}^{+} \mathrm{B}[41]$ \\
\hline $\begin{array}{l}\text { Total dissolved } \\
\text { solids (TDS) }\end{array}$ & $\mathrm{mg} \mathrm{L}^{-1}$ & $2540 \mathrm{C}[40]$ \\
\hline Total solids (TS) & $\mathrm{mg} \mathrm{L}^{-1}$ & 2540B [40] \\
\hline Surfactants & $\mathrm{mg} \mathrm{L}^{-1} \mathrm{MBAS}$ & $5540 \mathrm{C}[40]$ \\
\hline Temperature & ${ }^{\circ} \mathrm{C}$ & 2550B [40] \\
\hline Turbidity & NTU & $2130 \mathrm{~B}[40]$ \\
\hline Toxicity & & NBR 15411-3 [44] \\
\hline
\end{tabular}

MBAS: methylene blue active substances.

determine the minimum coagulant concentration that can be used without changing the color and turbidity removal. The statistical analyses were carried out using the Statistica $7{ }^{\circledR}$ software and considering a significance level of $5 \%$.

2.3. Evaluation of the MSP Parameters. The wastewater from the second batch underwent the C/F/S process in the best condition ( $\mathrm{pH}$ and coagulant concentration) according to the complementary assays after applying the Doehlert design. The resulting supernatant from this step was used as feed in the microfiltration (MF) and ultrafiltration (UF) membrane separation processes. The characteristics of the evaluated membranes are presented in Table 2 [46].

The filtration experiments were carried out in duplicate using a microfiltration membrane $(\mathrm{MF})$ in experimental bench unit [46] based on the cross-flow filtration principle. A representation of the experimental unit is shown in Figure 1.

The module was operated as a batch system with a total recycle of concentrates and permeates to the feed tank. The experiments were performed at room temperature $\left(\approx 25^{\circ} \mathrm{C}\right)$, with a flow of $0.5 \mathrm{~L} \cdot \mathrm{min}^{-1}$ for the MF membrane and $0.8 \mathrm{~L} \cdot \mathrm{min}^{-1}$ for the UF membrane and different transmembrane pressures $(0.6,1.0$, and $1.4 \mathrm{bar})$. The volumetric permeate flow $\dot{m}\left(\mathrm{~L} \mathrm{~h}^{-1}\right)$ was measured at different time intervals of 10 minutes during the filtration process, and the permeation flux $(J)\left(\mathrm{L} \mathrm{h}^{-1} \cdot \mathrm{m}^{-2}\right)$ was determined by equation (1), where $A$ is the membrane area $\left(\mathrm{m}^{2}\right)$ :

$$
J=\frac{\dot{m}}{A}
$$

When the permeate flux became constant, $200 \mathrm{~mL}$ of the permeate was collected for determining the color, turbidity, TOC, COD, TDS, and surfactants.
TABLE 2: Parameters of the ultrafiltration (UF) and microfiltration (MF) membranes.

\begin{tabular}{|c|c|c|}
\hline Parameter & UF & MF \\
\hline Geometry & Hollow fiber & Hollow fiber \\
\hline Material & $\begin{array}{l}\text { Poly(ether } \\
\text { sulfone) }\end{array}$ & Poly(imide) \\
\hline Selective layer & External & External \\
\hline Average pore diameter $(\mu \mathrm{m})$ & - & $0.4 \mu \mathrm{m}$ \\
\hline Molecular weight cut-off (kDa) & 50 & - \\
\hline Effective length (mm) & 260 & 260 \\
\hline Filtration area $\left(\mathrm{m}^{2}\right)$ & 0.027 & 0.027 \\
\hline
\end{tabular}

At the end of each experiment, the wastewater was drained and replaced by deionized water, measuring the flux of deionized water from the permeate of the dirt membrane. The flux decline (FF-\%) was calculated according to the following equation, where $J_{0}$ and $J_{\mathrm{d}}$ are the membrane flux $\left(\mathrm{L} \mathrm{h}^{-1} \cdot \mathrm{m}^{-2}\right)$ obtained with deionized water before and after the operation, respectively [47]:

$$
\mathrm{FF}(\%)=\left(1-\frac{J_{\mathrm{d}}}{J_{0}}\right) \times 100 \% \text {. }
$$

After each experimental assay, the membrane was submitted to a physical and chemical cleaning process until returning $90 \%$ of the initial flux (new membrane). The physical cleaning consisted of recirculating deionized water in the filtration module for approximately 2 minutes, being subsequently discarded. Then, the chemical cleaning consisted of recirculating a $\mathrm{NaOH} 3 \%$ solution during 40 minutes to remove the organic salts and other compounds that can cause incrustations. This procedure was followed by a rinsing step with deionized water during 5 minutes. Afterwards, another chemical cleaning process was performed with a citric acid $2 \%$ solution $\left(\mathrm{C}_{6} \mathrm{H}_{8} \mathrm{O}_{7}\right)$ for 20 minutes, followed again by a rinsing step with deionized water for 10 minutes [48, 49]. After finishing the cleaning process, the permeation flux using deionized water was measured and compared to the initial value (new membrane).

The performance of the MF and UF membranes was evaluated regarding the removal efficiency of color, TOC, COD, total nitrogen, TDS, surfactants, and turbidity. This parameter was calculated according to the following equation, where $R$ is the removal of the parameter (\%) and $C_{\mathrm{a}}$ and $C_{\mathrm{p}}$ are the values of the parameters measured in the feed and permeate samples, respectively [50]:

$$
R(\%)=\frac{C_{\mathrm{a}}-C_{\mathrm{p}}}{C_{\mathrm{a}}} \times 100 \% .
$$

2.4. Evaluation of the Combined C/F/S and Membrane Separation Process in the Best Experimental Conditions. In order to simulate the proposed treatment, the third batch of the laundry wastewater was used in the assay combining the best experimental conditions obtained from the $\mathrm{C} / \mathrm{F} / \mathrm{S}$ (coagulant concentration and $\mathrm{pH}$ ) and membrane filtration (type of membrane and transmembrane pressure) processes. The analyzed parameters in this experiment 


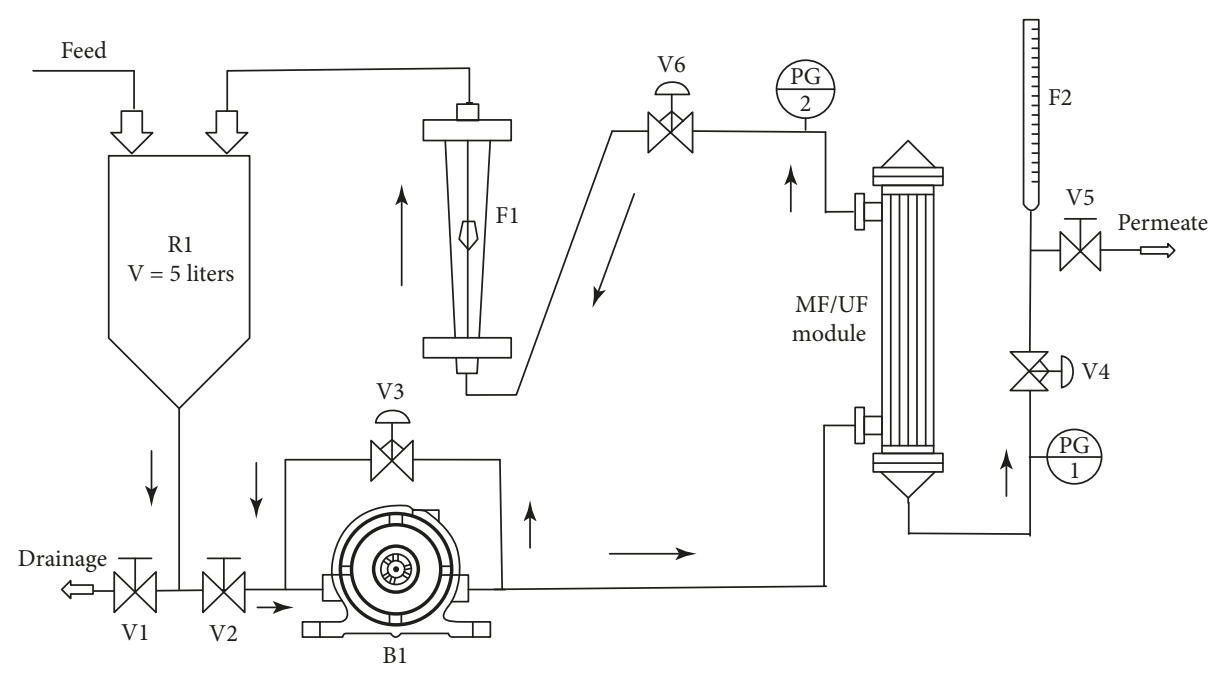

FIGURE 1: Schematic diagram of micro/ultrafiltration system (MF/UF, cross-flow hollow fiber membrane module; B1, pump; R1, feed tank; F1, F2, flowmeter; V6, back pressure valve; V1-V6, valves; PG1, PG2, pressure gauge).

were the thermotolerant coliforms, residual chlorine, color, turbidity, TOC, total nitrogen, COD, TDS, and surfactants, determining the removal efficiency according to equation (3).

\section{Results and Discussion}

3.1. Characterization of the Laundry Wastewater. The values of the laundry wastewater physicochemical parameters characterized for each of the three collected batches are presented in Table 3.

The results presented in Table 3 demonstrate variable physicochemical characteristics for the analyzed parameters. This variation among the obtained values can be related to the dirtiness present in the pieces of clothing within the period that the wastewater was collected since the higher the dirtiness, the higher the consumption of chemicals in the washing process.

The evaluated total organic carbon (TOC) values varied between 54.5 and $86 \mathrm{mg} \cdot \mathrm{C} \cdot \mathrm{L}^{-1}$, a parameter that represents the quantity of contaminating organic matter in the medium [51]. For color, the values ranged from 365 to $425 \mathrm{mg}_{\mathrm{Pt}-\mathrm{Co}}$ $\mathrm{L}^{-1}$. This behavior might be related to the type of items that were washed on the different collection days since the fabric can lose the color during the washing step.

The BOD values ranged from 58 to $87 \mathrm{mg} \mathrm{O}_{2} \mathrm{~L}^{-1}$, whereas the COD values from 245 to $587 \mathrm{mg} \mathrm{O}_{2} \mathrm{~L}^{-1}$. Ciabatti et al. [8] and Delforno et al. [52] obtained for the raw laundry wastewater COD mean values of $602 \mathrm{mg} \mathrm{O}_{2} \mathrm{~L}^{-1}$ and $1603 \mathrm{mg} \mathrm{O}_{2} \mathrm{~L}^{-1}$, respectively. According to the authors, the presence of anionic surfactants and fibrous materials in the wastewater might contribute to the increase in the COD value.

The total nitrogen parameter presented values within 2.9 and $7.1 \mathrm{mg} \cdot \mathrm{L}^{-1}$, which are lower than the one found by Braga and Varesche [3] when characterizing laundry wastewater $\left(32.4 \mathrm{mg} \cdot \mathrm{L}^{-1}\right)$. According to Lens et al. [53], the laundry wastewater has low quantities of nitrogen since it is a component hardly found in laundry additives.
TABle 3: Mean values ( \pm standard deviation) of the parameters analyzed when characterizing the laundry wastewater.

\begin{tabular}{lccc}
\hline Parameter & Batch 1 & Batch 2 & Batch 3 \\
\hline TOC $\left(\mathrm{mg} \cdot \mathrm{C} \cdot \mathrm{L}^{-1}\right)$ & $54.5 \pm 0.8$ & $80.4 \pm 1.2$ & $86.0 \pm 0.1$ \\
Conductivity $\left(\mu \mathrm{S} \cdot \mathrm{cm}^{-1}\right)$ & $278 \pm 13$ & $444 \pm 1$ & $647 \pm 8$ \\
Color $\left(\mathrm{mg}_{\left.\mathrm{Pt}-\mathrm{Co} \cdot \mathrm{L}^{-1}\right)}\right)$ & $394 \pm 11$ & $365 \pm 4$ & $425 \pm 0$ \\
BOD $\left(\mathrm{mg} \cdot \mathrm{O}_{2} \cdot \mathrm{L}^{-1}\right)$ & $58 \pm 0$ & $87 \pm 0$ & $67 \pm 0$ \\
COD $\left(\mathrm{mg} \cdot \mathrm{O}_{2} \cdot \mathrm{L}^{-1}\right)$ & $587 \pm 4$ & $383 \pm 15$ & $245 \pm 8$ \\
Total nitrogen $\left(\mathrm{mg} \cdot \mathrm{L}^{-1}\right)$ & $2.9 \pm 0$ & $7.1 \pm 0$ & $4.8 \pm 0$ \\
pH & $10.0 \pm 0.1$ & $10.5 \pm 0$ & $10.9 \pm 0$ \\
TDS $\left(\mathrm{mg} \cdot \mathrm{L}^{-1}\right)$ & $359 \pm 4$ & $471 \pm 2$ & $473 \pm 4$ \\
TS $\left(\mathrm{mg} \cdot \mathrm{L}^{-1}\right)$ & $456 \pm 6$ & $530 \pm 3$ & $532 \pm 7$ \\
Surfactants $\left(\mathrm{mg} \cdot \mathrm{L}^{-1} \mathrm{MBAS}\right)$ & $11.7 \pm 0.1$ & $19.6 \pm 0.1$ & $15.9 \pm 0$ \\
Temperature $\left({ }^{\circ} \mathrm{C}\right)$ & $23.4 \pm 0.2$ & $25.4 \pm 0.1$ & $25.1 \pm 0.1$ \\
Turbidity $(\mathrm{NTU})$ & $61 \pm 2$ & $52 \pm 2$ & $64 \pm 1$ \\
\hline
\end{tabular}

MBAS: methylene blue active substances.

The $\mathrm{pH}$ values measured in the present work were approximately 10. According to Kim et al. [17] and Delforno et al. [52], laundry wastewaters usually have high $\mathrm{pH}$ values due to the chemical additives used during the washing process such as softeners, bleach, and disinfectants. The same authors obtained $\mathrm{pH}$ values of 12.5 and 10 , respectively, when characterizing the laundry wastewater.

The quantity of anionic surfactant in the wastewater varied from 11.7 to $19.6 \mathrm{mg} \cdot \mathrm{L}^{-1}$ MBAS. According to Delforno et al. [52], these values are related to the concentration and dosage of detergent used in the washing process. The authors obtained $181 \mathrm{mg} \cdot \mathrm{L}^{-1} \mathrm{MBAS}$ of anionic surfactants when characterizing commercial laundry wastewater. As a result, they highlighted the relevance of treating this type of wastewater to reduce this parameter since a high quantity of surfactants can lead to the formation of foam and affect the water quality, besides occasioning toxicity.

According to Ahmad and El-Dessouky [2], the value of total dissolved solids (TDS) and total solids (TS) can be related to the presence of soaps and additives used in the washing process. In their work, the authors obtained a value of $504 \mathrm{mg} \cdot \mathrm{L}^{-1}$ for the TDS of a laundry wastewater, a value 
that is close to the ones obtained in this study when characterizing the wastewater (TDS: 359 to $473 \mathrm{mg} \cdot \mathrm{L}^{-1}$ and TS: 456 to $532 \mathrm{mg} \cdot \mathrm{L}^{-1}$ ).

The temperature of the wastewater obtained in the different batches was the room temperature $\left(23.4\right.$ to $25.4^{\circ} \mathrm{C}$ ). This parameter is relevant since high temperatures reduce the quantity of dissolved oxygen in the receiving water bodies, consequently affecting the aquatic fauna.

The obtained turbidity ranged from 52 to 64 NTU. These values were lower than the one obtained by Nicolaidis and Virydes [11] when characterizing laundry wastewater (92 NTU). According to Huang et al. [54], the turbidity value is a quality indicator of colloidal substances present in the wastewater.

The results obtained from the industrial laundry wastewater characterization indicate the necessity to remove the organic matter and other contaminants before the discharge into the water bodies. For this purpose, the utilization of a $\mathrm{C} / \mathrm{F} / \mathrm{S}$ treatment to remove the solids in suspension associated with a membrane separation process is in agreement with the reduction of the content of these contaminants and their harmful effects in the ecosystem.

\subsection{Determination of the $C / F / S$ Optimized Parameters.}

Table 4 presents the values of the response variables color removal (\%) and turbidity (\%) for each $\mathrm{C} / \mathrm{F} / \mathrm{S}$ condition (batch 1) predicted in the Doehlert design.

With a coagulant concentration of $60 \mathrm{mg} \cdot \mathrm{L}^{-1}$, when reducing the $\mathrm{pH}$ from 7.2 to 5.5 , the efficiency of color and turbidity removal increased to $34.5 \%$ and $28.9 \%$, respectively. The same behavior was not obtained with the concentration of $120 \mathrm{mg} \cdot \mathrm{L}^{-1}$ and reducing the $\mathrm{pH}$ from 8.0 to 6.3 , resulting in an increase of, approximately, $11 \%$ of the removal of both parameters. Nevertheless, the removal efficiencies did not change when modifying the wastewater $\mathrm{pH}$ to 4.6. With the highest coagulant concentration $\left(180 \mathrm{mg} \cdot \mathrm{L}^{-1}\right)$, the $\mathrm{pH}$ reduction from 7.2 to 5.5 also provided a decrease in the color $(\approx 27 \%)$ and turbidity $(\approx 24 \%)$ removal. According to Beltrán-Heredia et al. [55], there is a precise coagulant dosage in which the formation of flocs effectively occurs due to their cationic nature. Therefore, as observed for the concentrations of 60 and $120 \mathrm{mg} \cdot \mathrm{L}^{-1}$, the cationic nature of the coagulant results in higher removal of color and turbidity with acidic $\mathrm{pH}$ values (5.5 and 6.3).

The analysis of variance (ANOVA) allows the evaluation of the performance of the regression model, and its validation is determined by the F-test. Table 5 presents the analysis of variance (ANOVA) for the removal of color and turbidity of the wastewater.

The $F$-test for the model presented a $F_{\text {table }}$ value lower than the $F_{\text {calc }}$ for the color $(3.11<273.99)$ and turbidity $(3.11<33.96)$ responses, indicating that the regression fitted to the proposed model for both parameters (color and turbidity). The $F_{\text {calc }} / F_{\text {table }}$ ratio was 88.09 for color and 10.91 for turbidity, indicating a high correlation value for the proposed model. According to Montgomery [56], when the $F_{\text {calc }} / F_{\text {table }}$ ratio is higher than 4 , the model is statistically significant, whereas for values higher than 10 , in addition to significant, the model is predictive.

For the color and turbidity responses, the residual plots (not shown) did not indicate the presence of outliers (out of the interval -2 to 2 ), i.e., the points were randomly distributed around zero, therefore confirming the normal distribution for color and turbidity.

The regression coefficients for the proposed Doehlert experimental design are presented in Table 6.

From the analysis of effects (Table 6), it can be verified that only the quadratic term of the $\mathrm{pH}$ for turbidity presented a $p$ value higher than 0.05 , and it was not significant. However, as the value 0.0517 is close to 0.05 , this term was considered for validating the model. The other variables were significant ( $p$ value $<0.05$ ).

As the proposed model was validated, the equations (4) and (5) were applied for determining the percentage of removal of color and turbidity, respectively, where [CC] is the coagulant concentration:

$$
\begin{aligned}
\operatorname{color} \text { removal }(\%)= & 91.4583-2.0450[\mathrm{pH}]-1.2933[\mathrm{pH}]^{2} \\
& +2.63[\mathrm{CC}]-16.415[\mathrm{CC}]^{2} \\
& +15.65[\mathrm{pH}][\mathrm{CC}]
\end{aligned}
$$

turbidity removal $(\%)=93.8917-2.3121[\mathrm{pH}]$

$$
\begin{aligned}
& -1.3504[\mathrm{pH}]^{2}+4.0263[\mathrm{CC}] \\
& -14.3875[\mathrm{CC}]^{2}+13.2362[\mathrm{pH}][\mathrm{CC}],
\end{aligned}
$$

where $60 \leq \mathrm{CC} \leq 180 \mathrm{mg} \cdot \mathrm{L}^{-1}$ and $4.5 \leq \mathrm{pH} \leq 8$.

In order to determine the best operating ranges for $\mathrm{pH}$ and coagulant concentration that provide the highest removal (\%) of color and turbidity, the response surface methodology and contour plots were evaluated (Figure 2).

The response surface represents the influence of the $\mathrm{pH}$ and coagulant concentration on the removal of color (Figure 2(a)) and turbidity (Figure 2(b)) of the wastewater. A similar behavior was observed for both responses, in which the plots were saddle-shaped, and the central points were close to the best experimental condition. For $\mathrm{pH}$ values close to the neutrality (7 to 8) and high coagulant concentrations (140 to $180 \mathrm{mg} \cdot \mathrm{L}^{-1}$ ), as well as for low $\mathrm{pH}$ values (4.6 to 5.5 ) and concentrations (60 to $120 \mathrm{mg} \cdot \mathrm{L}^{-1}$ ), the results indicated the maximum removal of color and turbidity. Nevertheless, considering that the initial wastewater $\mathrm{pH}$ is approximately 10 , this implies that lower $\mathrm{pH}$ values require a higher quantity of the acidic solution in order to adjust it, just as alkaline $\mathrm{pH}$ values that require a higher quantity of coagulant, consequently increasing the cost of the process. Therefore, to obtain an efficient and cost-effective $\mathrm{C} / \mathrm{F} / \mathrm{S}$ process, intermediary $\mathrm{pH}$ values and coagulant concentrations can be applied.

The critical values obtained from the statistical model with the $\mathrm{pH}$ varying from 4.6 to 8 and coagulant concentrations varying from 60 to $180 \mathrm{mg} \cdot \mathrm{L}^{-1}$ for the response of color and turbidity were a pH of 6.4 and concentrations of $129.5 \mathrm{mg} \cdot \mathrm{L}^{-1}$ and $132.1 \mathrm{mg} \cdot \mathrm{L}^{-1}$, respectively. The values determined for the 
TABle 4: Doehlert design matrix and removal of color and turbidity of the wastewater (batch 1) using the Tanfloc POP ${ }^{\circledR}$ coagulant.

\begin{tabular}{lcccccc}
\hline Run & Level $\mathrm{pH}$ & $\mathrm{pH}$ & Level concentration & Concentration $\left(\mathrm{mg} \mathrm{L}^{-1}\right)$ & Color $(\%)$ & Turbidity (\%) \\
\hline 1 & -1 & 4.6 & 0 & 120 & $90.83 \pm 0.2$ & $94.24 \pm 1.7$ \\
2 & -0.5 & 5.5 & 0.8 & 180 & $62.33 \pm 1.0$ & $70.14 \pm 2.8$ \\
3 & -0.5 & 5.5 & -0.8 & 60 & $88.37 \pm 5.0$ & $88.56 \pm 6.3$ \\
4 & 0 & 6.3 & 0 & 120 & $91.09 \pm 2.1$ & $94.34 \pm 4.6$ \\
5 & 0 & 6.3 & 0 & 120 & $91.85 \pm 1.3$ & $94.23 \pm 1.3$ \\
6 & 0 & 6.3 & -0.8 & 120 & $53.91 \pm 1.6$ & $93.12 \pm 2.8$ \\
7 & 0.5 & 7.2 & 0.8 & 60 & $89.67 \pm 5.9$ & $59.70 \pm 8.7$ \\
8 & 0.5 & 7.2 & 0 & 180 & $81.75 \pm 4.3$ & $84.23 \pm 1.3$ \\
9 & 1 & 8.0 & & 120 & $82.74 \pm 1.9$ \\
\hline
\end{tabular}

Operating conditions: 2 minutes of rapid mixing $(120 \mathrm{rpm}), 15$ minutes of slow mixing (20 rpm), and 10 minutes of sedimentation.

TABle 5: Analysis of variance (ANOVA) of the Doehlert design for the removal (\%) of color and turbidity $(\alpha=0.05)$.

\begin{tabular}{lccccccc}
\hline \multirow{2}{*}{ Source of variation } & \multicolumn{3}{c}{ Color } & \multicolumn{3}{c}{ Turbidity } \\
& SQ & DF & MS & $F_{\text {calc }}$ & SQ & DF & MS \\
\hline Regression $(d)$ & 3328.979 & 5 & 665.796 & 273.99 & 2548.89 & 5 & 509.78 \\
Lack of fit $(a)$ & 2.430 & 1 & 2.430 & 0.2685 & 15.075 & 1 & 15.075 \\
Pure error $(b)$ & 99.551 & 11 & 9.050 & & 165.082 & 11 & 15.007 \\
Residues $(a+b=c)$ & 101.981 & 12 & 8.498 & & 180.158 & 12 & 15.013 \\
Total $(c+d)$ & 3532.942 & 17 & & & 2729.051 & 17 & \\
\hline
\end{tabular}

$\mathrm{SQ}=$ sum of squares; $\mathrm{DF}=$ degrees of freedom; $\mathrm{MS}=$ mean of squares; $F_{\text {calc }}=\mathrm{F}$ calculated. Color: $F_{\text {table }}(5 ; 12 ; 0.05)=3.11 ; R^{2}=0.97 ; R_{\text {model }}^{2}=0.957$. Turbidity: $F_{\text {table }}(5 ; 12 ; 0.05)=3.11 ; R^{2}=0.934 ; R_{\text {model }}^{2}=0.906$.

TABLE 6: Effects for the removal of color and turbidity of the wastewater (batch 1).

\begin{tabular}{|c|c|c|c|c|c|c|}
\hline \multirow{2}{*}{ Variables } & \multicolumn{3}{|c|}{ Color } & \multicolumn{3}{|c|}{ Turbidity } \\
\hline & Coefficient & Pure error & $p$-value & Coefficient & Pure error & $p$-value \\
\hline Intercept & 91.4583 & 1.1901 & 0 & 93.8917 & 1.5818 & 0 \\
\hline $\mathrm{pH}(\mathrm{L})^{+}$ & -2.0450 & 0.5950 & 0.0049 & -2.3121 & 0.7909 & 0.0127 \\
\hline $\mathrm{pH}(\mathrm{Q})$ & -1.2933 & 0.4704 & 0.0176 & -1.3504 & 0.6252 & 0.0517 \\
\hline Coagulant concentration $\left(\mathrm{mg} \mathrm{L}^{-1}\right)(\mathrm{L})$ & 2.6300 & 1.0306 & 0.0253 & 4.0263 & 1.3699 & 0.0123 \\
\hline Coagulant concentration $\left(\mathrm{mg} \mathrm{L}^{-1}\right)(\mathrm{Q})$ & -16.4150 & 1.4113 & 0 & -14.3875 & 1.8758 & 0 \\
\hline $\mathrm{pH} \times$ concentration & 15.6500 & 1.0306 & 0 & 13.2362 & 1.3699 & 0 \\
\hline
\end{tabular}

(L): linear regression parameter; $(\mathrm{Q})$ : quadratic regression parameter.

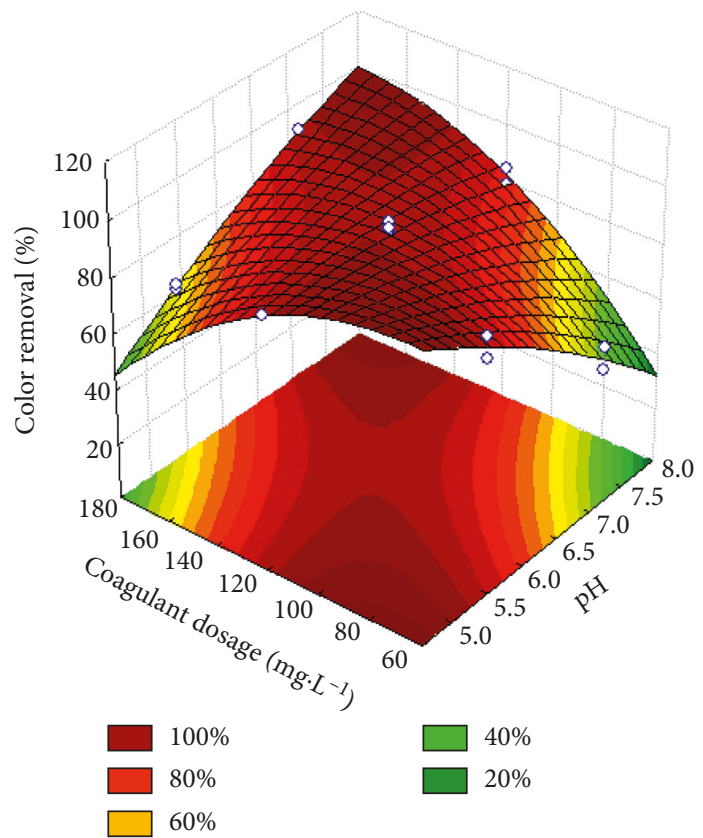

(a)

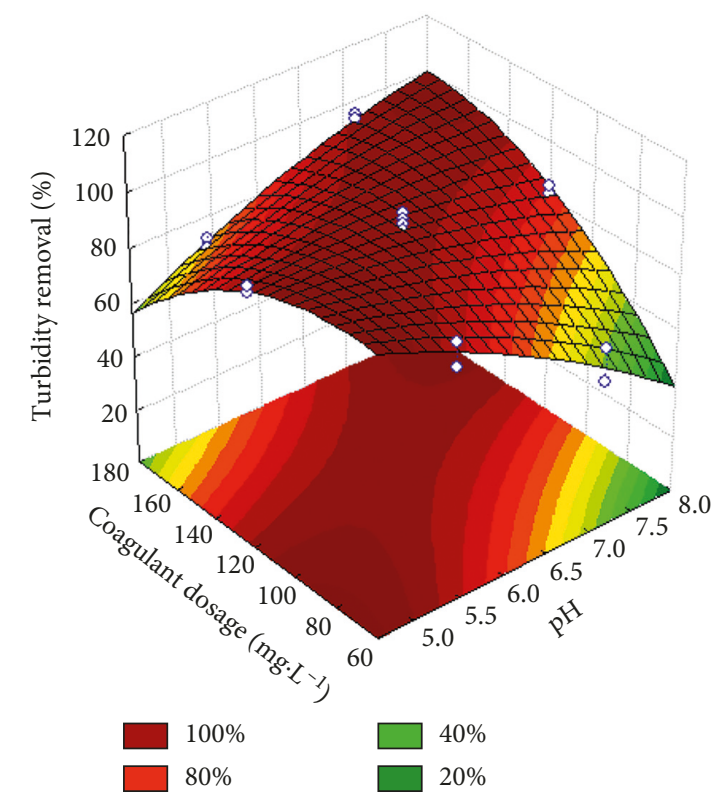

(b)

Figure 2: Continued. 


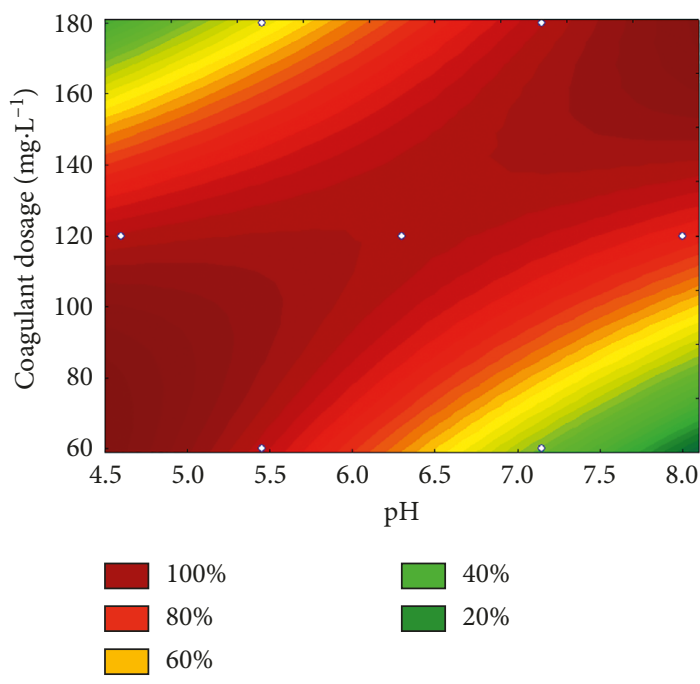

(c)

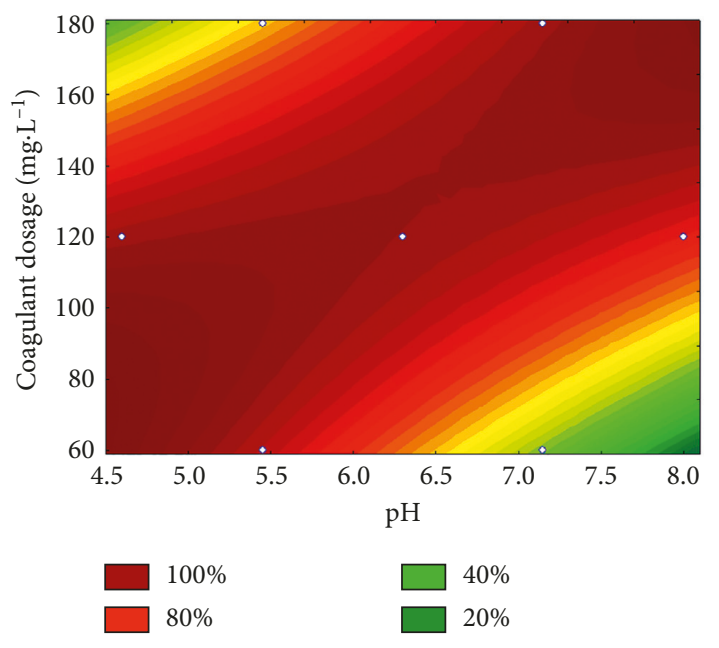

(d)

FIGURE 2: Response surface for removal (\%) of color (a) and turbidity (b) and contour plots for the removal (\%) of color (c) and turbidity (d) of the laundry wastewater by Tanfloc POP ${ }^{\circledR}$.

maximum removal of color (94.14\%) and turbidity $(91.50 \%)$ were obtained using equations (4) and (5). The mean critical values obtained from the coagulant concentration and the response of color and turbidity were $130.8 \mathrm{mg} \cdot \mathrm{L}^{-1}$ and a $\mathrm{pH}$ of 6.4. According to these results, new $\mathrm{C} / \mathrm{F} / \mathrm{S}$ experiments with the laundry wastewater were carried out varying the coagulant concentration between 100 and $130 \mathrm{mg} \cdot \mathrm{L}^{-1}$ in a $\mathrm{pH}$ of 6.4 . It was performed to reach the highest removal efficiency with the lowest coagulant concentration.

The results regarding the removal of color and turbidity were evaluated through the analysis of variance (not shown), demonstrating that there was a significant difference ( $p$-value $<0.05)$ between the treatments (coagulant concentration) for the color parameter. Since the turbidity parameter is not influenced by the coagulant concentration ( $p$ value $>0.05$ ), a comparison of means was performed to identify the treatments that presented the same means only for color removal.

The percentages of removal of color and turbidity and the comparison of means (Fisher's LSD test) for the color parameter using different concentrations of the Tanfloc POP ${ }^{\circledR}$ coagulant are presented in Table 7.

The results demonstrated that the concentrations of 120 and $130 \mathrm{mg} \cdot \mathrm{L}^{-1}$ presented different means of color removal. However, this increase in the concentration resulted in an increment of only $3.5 \%$ in the removal of color (Table 7 ), requiring a higher quantity of coagulant and increasing the cost of the process. For the concentration of $100 \mathrm{mg} \cdot \mathrm{L}^{-1}$, the minimum removal of color $(66.92 \%)$ was obtained, indicating an insufficient coagulant concentration.

For the concentrations of $110 \mathrm{mg} \cdot \mathrm{L}^{-1}$ and $120 \mathrm{mg} \cdot \mathrm{L}^{-1}$, there was no significant difference ( $p$-value $>0.05)$ among the color removal means. Therefore, aiming at an efficient and cost-effective process, a coagulant concentration of $110 \mathrm{mg} \cdot \mathrm{L}^{-1}$ (80.27\% of color; $86.50 \%$ of turbidity) was chosen for the combined $\mathrm{C} / \mathrm{F} / \mathrm{S}$ and membrane separation process.
TABLE 7: Removal of color and turbidity and comparison of means (Fisher's LSD test) for the color parameter.

\begin{tabular}{lcc}
\hline $\begin{array}{l}\text { Treatment (coagulant } \\
\text { concentration, mg. } \mathrm{L}^{-1} \text { ) }\end{array}$ & $\begin{array}{c}\text { Removal of } \\
\text { color }(\%)\end{array}$ & $\begin{array}{c}\text { Removal of } \\
\text { turbidity }(\%)\end{array}$ \\
\hline 100 & $66.92^{\mathrm{c}}$ & 82.23 \\
110 & $80.27^{\mathrm{b}}$ & 86.50 \\
120 & $80.27^{\mathrm{b}}$ & 85.83 \\
130 & $83.76^{\mathrm{a}}$ & 89.76 \\
\hline
\end{tabular}

Same letters indicate the same means for the removal of color among the treatments ( $p$ value $>0.05$ ).

3.3. Evaluation of MSP Parameters. For the membrane separation experiments, the supernatant from the second batch was used after submitting it to the $\mathrm{C} / \mathrm{F} / \mathrm{S}$ process applying $110 \mathrm{mg} \cdot \mathrm{L}^{-1}$ of coagulant and a $\mathrm{pH}$ of 6.4 .

Figure 3 shows the behavior of the permeation flux $(J)$ as a function of time for the MF and UF membranes at different pressures, as well as their standard deviations.

The permeation curves for both membranes presented a similar behavior. It can be observed a fast reduction of the permeation flux in the first 10 minutes of filtration, and then it slowly reduces until the stabilization from 90 minutes to 50 minutes for the MF and UF membranes, respectively. This reduction of the permeation flux is due to the fouling process, which occurs because of the interaction among the material of the membrane and the other components in the wastewater that deposit on its surface $[8,20,57]$.

Samples of the permeate were collected in 110 minutes of filtration and then analyzed regarding color, TOC, COD, total nitrogen, $\mathrm{pH}$, TDS, surfactants, and turbidity. Table 8 presents the quantified physicochemical parameters of the feeding samples (supernatant obtained after the C/F/S process using batch 2), removal efficiencies (\%), average permeation flux, and fouling from the membranes for each experimental condition. 


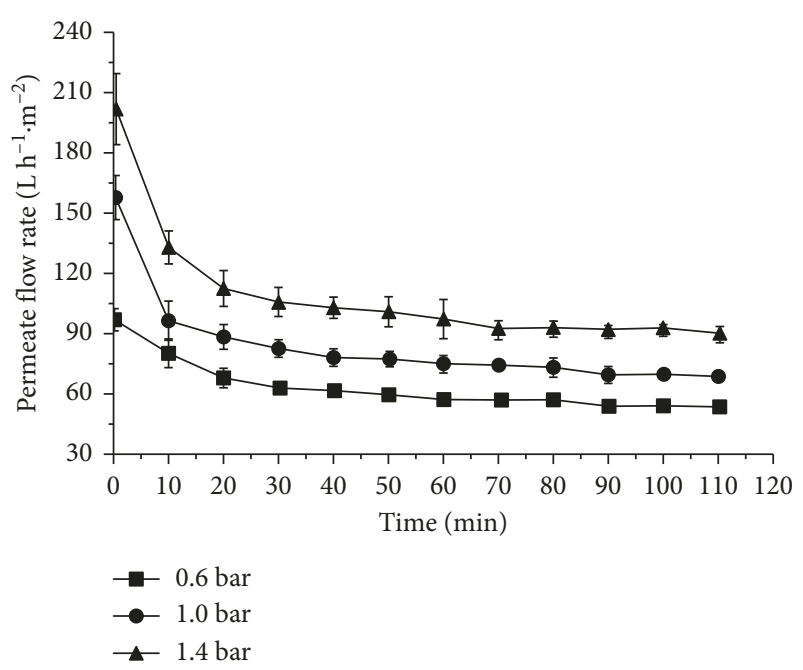

(a)

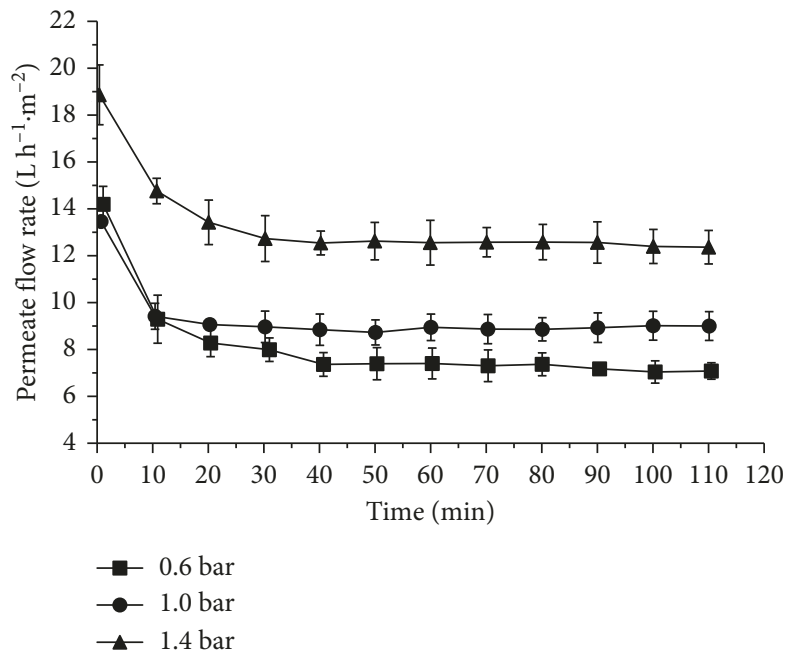

(b)

Figure 3: Permeation flux $(J)$ as a function of time for different transmembrane pressures: (a) MF membrane (flow of $0.5 \mathrm{~L} \cdot \mathrm{min}^{-1}$ ) and $(\mathrm{b})$ UF membrane (flow of $0.8 \mathrm{~L} \cdot \mathrm{min}^{-1}$ ).

TABle 8: Performance of the MF and UF membranes in the experiments with different transmembrane pressures (batch 2).

\begin{tabular}{|c|c|c|c|c|c|c|c|}
\hline \multirow{2}{*}{ Parameter } & \multirow{2}{*}{ Feed $^{* *}$} & \multicolumn{3}{|c|}{ MF (\% removal) } & \multicolumn{3}{|c|}{ UF (\% removal) } \\
\hline & & 0.6 bar & $1.0 \mathrm{bar}$ & $1.4 \mathrm{bar}$ & 0.6 bar & $1.0 \mathrm{bar}$ & $1.4 \mathrm{bar}$ \\
\hline Color $\left(\mathrm{mg}_{\mathrm{Pt}-\mathrm{Co}} \cdot \mathrm{L}^{-1}\right)$ & $113.0 \pm 1.4$ & 93 & 94 & 98 & 88 & 88 & 90 \\
\hline $\operatorname{TOC}\left(\mathrm{mg} \cdot \mathrm{C} \cdot \mathrm{L}^{-1}\right)$ & $53.1 \pm 1.4$ & 37.2 & 53 & 42 & 52.6 & 47.3 & 56.6 \\
\hline $\mathrm{COD}\left(\mathrm{mg} \cdot \mathrm{O}_{2} \cdot \mathrm{L}^{-1}\right)$ & $219 \pm 8$ & 73 & 73 & 77 & 52 & 67 & 92 \\
\hline Total nitrogen $\left(\mathrm{mg} \cdot \mathrm{TN} \cdot \mathrm{L}^{-1}\right)$ & $6.9 \pm 0$ & 36.1 & 45.5 & 44.6 & 38 & 43.5 & 40.1 \\
\hline TDS $\left(\mathrm{mg} \cdot \mathrm{L}^{-1}\right)$ & $431 \pm 6$ & 8.4 & 43.7 & 49.5 & 27.1 & 47.4 & 50.5 \\
\hline Surfactants (mg L $\left.{ }^{-1} \mathrm{MBAS}\right)$ & $9.5 \pm 1$ & 5.8 & 8.9 & 5.8 & 27.8 & 30.9 & 36.1 \\
\hline Turbidity (NTU) & $11.9 \pm 0.1$ & 95 & 97 & 97 & 91 & 93 & 96 \\
\hline $\mathrm{pH}$ & 6.4 & 6.8 & 6.8 & 6.6 & 6.8 & 6.8 & 6.9 \\
\hline${ }^{*}$ Mean flux $\left(\mathrm{L} \cdot \mathrm{h}^{-1} \cdot \mathrm{m}^{-2}\right)$ & - & $53.9 \pm 0.3$ & $71.5 \pm 0.3$ & $92.2 \pm 0.5$ & $7.3 \pm 0.2$ & $8.9 \pm 0.1$ & $12.5 \pm 0.1$ \\
\hline Fouling (\%) & - & 55.3 & 59.4 & 60.2 & 73.1 & 77.4 & 76.7 \\
\hline
\end{tabular}

${ }^{*}$ Mean fluxes obtained between 90 and $110 \mathrm{~min}(\mathrm{MF})$ and between 50 and $110 \mathrm{~min}(\mathrm{UF}) .{ }^{* *}$ Characteristics of the wastewater after the C/F/S process.

A linear increase of the permeation flux was observed with the increment of the transmembrane pressure for both membranes (MF and UF) (Table 8). The values of the permeation flux for the MF membrane were higher than the ones for the UF membrane since the first presents larger pores. The mean permeability, estimated between 0.6 and 1.4 bar, was 75.73 and $9.99 \mathrm{~L} \cdot \mathrm{h}^{-1} \cdot \mathrm{m}^{-2} \cdot \mathrm{bar}^{-1}$ for the MF and UF membranes, respectively. With the pressure of $1.4 \mathrm{bar}$, the highest permeation fluxes were obtained (MF: $92.2 \mathrm{~L} \cdot \mathrm{h}^{-1} \cdot \mathrm{m}^{-2}$ and UF: $12.5 \mathrm{~L} \cdot \mathrm{h}^{-1} \cdot \mathrm{m}^{-2}$ ). According to these results, it can be verified that an increase of the transmembrane pressure results in a higher driving force, allowing the liquid to easily cross the pores of the membrane [57].

The fouling values observed for the assays with the UF membrane were higher than the ones with the MF (Table 8). The increase in the transmembrane pressure also resulted in an increase of the fouling values for both membranes. In fact, the filtration of the wastewater containing material in suspension causes its decomposition on the surface of the membrane, which implies in higher values for the flux decline $[58,59]$.
These results support the ones obtained by PeterVarbanets et al. [60] when treating river water with the UF membrane $(0.04,0.15,0.25$, and 0.50 bar). The authors observed an increase in the fouling values with the increment of the operating pressure.

The $\mathrm{pH}$ of the permeate samples presented a variation between 0.2 and 0.5 when compared to the feeding $\mathrm{pH}$ values (6.4). A similar behavior was obtained by Ciabattia et al. [8] when treating laundry wastewater by UF and using membranes manufactured from polyvinylidene fluoride (PVDF). For these authors, the $\mathrm{pH}$ value of the permeate (7.3) was practically unchanged compared to the feeding value (7.2).

The other parameters analyzed in the present study presented a reduction when compared to the feeding values (supernatant from the $\mathrm{C} / \mathrm{F} / \mathrm{S}$ process), confirming the efficiency of the membrane separation process (Table 8 ) when treating the laundry wastewater. The increase of the operating pressure resulted in a higher removal of the evaluated parameters, with the exception of the TOC and total nitrogen for both membranes and surfactants for the MF membrane. 
The color and turbidity parameters were the ones that presented the highest removal efficiencies (between 88 and $98 \%$ ), even when applying the lowest pressure (0.6 bar) for the MF and UF membranes. The treated color can be further improved using nanofiltration [61].

The performance of the membranes regarding the removal of COD increased with the filtration pressure, obtaining the maximum values of $77 \%$ for the MF and $92 \%$ for the UF (Table 8). Regarding the laundry wastewater treatment performed by Manouchehri and Kargari [10] and applying the MF acrylic membrane (Plexiglass ${ }^{\mathrm{TM}}$ ), removal between 73.4 and $89.8 \%$ of COD was obtained within a pressure range of 0.2 to $1.5 \mathrm{bar}$. The authors verified the highest removal $\left(89.8 \%, \mathrm{COD}_{\text {initial }}=2538 \mathrm{mg} \mathrm{O}_{2} \mathrm{~L}^{-1}\right)$ with the operating pressure of 0.5 bar.

The TOC parameter presented removal between 37.2 and $56.6 \%$ using the MF and UF membranes at the tested pressures (Table 8 ). In the study conducted by Guilbaud et al. [9], treating a laundry wastewater on board a ship (with clothes, tablecloths, bath towels, napkins, etc.), the removal of TOC was $98 \%\left(\right.$ TOC $_{\text {initial }}: 503 \mathrm{mg} \cdot \mathrm{C} \cdot \mathrm{L}^{-1}$; TOC $_{\text {permeate: }}$ : $10 \mathrm{mg} \cdot \mathrm{C} \cdot \mathrm{L}^{-1}$ ) using only the nanofiltration (NF) process at the pressure of 35 bar. Nevertheless, it should be considered that the NF process is more restrictive regarding the transfer of the components present in the wastewater and demands more energy in order to operate. Therefore, the TOC values for the permeate $\left(\approx 23 \mathrm{mg} \cdot \mathrm{C} \cdot \mathrm{L}^{-1}\right)$ obtained with the $\mathrm{MF}$ and UF membranes after the $\mathrm{C} / \mathrm{F} / \mathrm{S}$ process demonstrated to be satisfactory considering the characteristics of the laundry wastewater evaluated and the energy costs.

The removal efficiencies of total nitrogen (Table 8) after the treatment steps were similar comparing the same pressures between the MF and UF membranes. The maximum total nitrogen removal regarding the feeding concentration $\left(6.9 \mathrm{mg} \cdot \mathrm{L}^{-1}\right)$ was $45.5 \%$ for the MF and $43.5 \%$ for the UF at 1.0 bar. In the research work of Šstar-Turk et al. [7], also treating laundry wastewater samples, the authors obtained a removal of $98.9 \%$ for total nitrogen $\left(C_{\text {initial }}=2.75 \mathrm{mg} \cdot \mathrm{L}^{-1}\right)$ using a ceramic UF membrane with a cut diameter between 20 and $400 \mathrm{kDa}$ with pressures from 3 to 5 bar. In a different way, in this research work, the UF membrane utilized was the polymeric one (polyethersulfone) with a cut diameter of $50 \mathrm{kDa}$ and a more reduced operating pressure $(1.0 \mathrm{bar})$. Along with the wastewater characteristics, these conditions influenced the performance of the process.

The membrane separation step presented the maximum removal of surfactants (Table 8 ) at the pressure of 1.0 bar for the MF membrane (9.5 for $8.65 \mathrm{mg} \cdot \mathrm{L}^{-1} ; 8.9 \%$ ) and 1.4 bar for the UF (9.5 for $\left.6.07 \mathrm{mg} \cdot \mathrm{L}^{-1} ; 36.1 \%\right)$. This value was close to the removal of surfactants obtained by Šostar-Turk et al. [7] utilizing the UF (10.06 for $\left.7.02 \mathrm{mg} \cdot \mathrm{L}^{-1}\right)$.

The TDS value $\left(431 \mathrm{mg} \cdot \mathrm{L}^{-1}\right)$ reduced with the increase of the operating pressure for the MF and UF membranes (Table 8), reaching removal of, approximately, $50 \%$ at 1.4 bar. Manouchehri and Kargari [10] also evaluated the TDS reduction for the laundry wastewater treatment applying MF and obtained $25.2 \%$ of removal at the pressure of 1.0 bar. The value of this parameter (TDS) is relevant since it provides the quantity of organic and inorganic substances in the wastewater in the form of suspensions even after the treatments [62].

The MF membrane at a pressure of 1.4 bar presented for the most part, with the exception of surfactants, the highest removal efficiencies for the parameters in general, as well as the highest mean permeation flux $\left(92.2 \mathrm{~L} \cdot \mathrm{h}^{-1} \cdot \mathrm{m}^{-2}\right.$ ) (Table 8), an aspect that is required by the industry.

3.4. Evaluation of the Combined C/F/S and Membrane Separation Process at the Best Experimental Conditions. The laundry wastewater (batch 3) was submitted to the combined $\mathrm{C} / \mathrm{F} / \mathrm{S}-\mathrm{MF}$ process at the optimized experimental conditions previously obtained from the $\mathrm{C} / \mathrm{F} / \mathrm{S}$ steps for 10 minutes of sedimentation $\left(110 \mathrm{mg} \cdot \mathrm{L}^{-1}\right.$ of coagulant; $\mathrm{pH}$ of 6.4 ) and membrane separation (1.4 bar).

The removal efficiencies of the physicochemical parameters for each treatment step are presented in Table 9, as well as the total removal efficiencies that are related to the final removal obtained from the combined process $(\mathrm{C} / \mathrm{F} / \mathrm{S}$ $\mathrm{MF})$ regarding the raw wastewater.

The TOC parameter (Table 9) reduced roughly $50 \%$ in the $\mathrm{C} / \mathrm{F} / \mathrm{S}$ step and $13 \%$ in the membrane filtration (MF), reaching the value of $37.6 \mathrm{mg} \cdot \mathrm{C} \cdot \mathrm{L}^{-1}$ for the permeate. Mozia et al. [63] treated a laundry wastewater from hotels by a combined biological process followed by $\mathrm{UV} / \mathrm{O}_{3}$ oxidation and UF $(150 \mathrm{kDa})$ and obtained a TOC removal of $29 \%$ in the UF step at 2 bar $\left(7.9 \mathrm{mg} \cdot \mathrm{C} \cdot \mathrm{L}^{-1}\right.$ in the permeate) and $95 \%$ $\left(\mathrm{TOC}_{\text {initial }}=172 \mathrm{mg} \cdot \mathrm{C} \cdot \mathrm{L}^{-1}\right)$ by the combined process. It is important to notice that the total efficiency obtained for the TOC removal $\left(56.3 \%\right.$, TOC $\left._{\text {initial }}: 86 \mathrm{mg} \cdot \mathrm{C} \cdot \mathrm{L}^{-1}\right)$ for the industrial laundry wastewater studied was related to a lower operating time (C/F/S: 10 minutes of sedimentation) for the step that precedes the MF when compared to the oxidative process (12 hours).

The color and turbidity parameters presented removal of $83.3 \%$ and $91.3 \%$ in the C/F/S step and 90.1 and $89.3 \%$ in the MF step, respectively. The total removal for color was $98.4 \%$ and $99.1 \%$ for turbidity. These results demonstrated that the combined process $(\mathrm{C} / \mathrm{F} / \mathrm{S}-\mathrm{MF})$ for treating the industrial laundry wastewater was efficient in removing these parameters, resulting in treated water with better quality. Shang et al. [18] treated laundry wastewater (initial turbidity of $735 \mathrm{NTU}$ ) by a combined C/F/S-MF process and obtained a removal of $90 \%$ for turbidity in the C/F/S step utilizing a polymer as coagulant and $100 \%$ after the MF process with PVDF membranes.

The COD value $\left(245 \mathrm{mg} \mathrm{O}_{2} \mathrm{~L}^{-1}\right)$ for the raw wastewater reduced to $83 \mathrm{mg} \mathrm{O}_{2} \mathrm{~L}^{-1}$ (66.1\%) after utilizing the $\mathrm{C} / \mathrm{F} / \mathrm{S}$ step, and in the MF process, the permeate presented $77 \mathrm{mg} \mathrm{O}_{2} \mathrm{~L}^{-1}$, reaching a total efficiency of $68.6 \%$ of COD removal. This result satisfies the value required by the legislation of Paraná state (CEMA/IAP: 70/2009) [64] of $200 \mathrm{mg} \mathrm{O}_{2} \mathrm{~L}^{-1}$ for the discharge of laundry wastewater. Authors, for example, Shang et al. [18], reached removal of $50 \%$ for COD by the C/F/S process $\left(\mathrm{COD}_{\text {initial: }} 1196 \mathrm{mg} \mathrm{O}_{2} \mathrm{~L}^{-1}\right)$ for the laundry wastewater and, after the MF process, a total efficiency of 55 to $65 \%$ with the maximum pressure of 1.37 bar. 
TABLE 9: Physicochemical parameters analyzed for the raw wastewater (batch 3), treated by C/F/S and microfiltration (MF), and removal efficiencies (\%).

\begin{tabular}{|c|c|c|c|c|c|c|}
\hline \multirow{2}{*}{ Parameter } & \multirow{2}{*}{$\begin{array}{c}\text { Raw wastewater } \\
\text { Value }\end{array}$} & \multicolumn{2}{|c|}{$\mathrm{C} / \mathrm{F} / \mathrm{S}$ step (supernatant) } & \multicolumn{2}{|c|}{ MF step (permeate) } & \multirow{2}{*}{ Total removal C/F/S-MF (\%) } \\
\hline & & Value & Removal (\%) & Value & Removal (\%) & \\
\hline TOC $\left(\mathrm{mg} \mathrm{C} \mathrm{L}^{-1}\right)$ & $86.0 \pm 0.1$ & $43.3 \pm 0.3$ & 49.7 & $37.6 \pm 3.1$ & 13.2 & 56.3 \\
\hline Color $\left(\mathrm{mg}_{\mathrm{Pt}-\mathrm{Co}} \mathrm{L}^{-1}\right)$ & $425 \pm 0$ & $71 \pm 1$ & 83.3 & $7 \pm 1.4$ & 90.1 & 98.4 \\
\hline $\mathrm{COD}\left(\mathrm{mg} \mathrm{O}_{2} \mathrm{~L}^{-1}\right)$ & $245 \pm 8$ & $83 \pm 3$ & 66.1 & $77 \pm 0$ & 7.2 & 68.6 \\
\hline Total nitrogen $\left(\mathrm{mg} \mathrm{TN} \mathrm{L}^{-1}\right)$ & $4.8 \pm 0$ & $3.9 \pm 0$ & 18.8 & $3.5 \pm 0.1$ & 10.3 & 27.1 \\
\hline $\mathrm{pH}$ & $10.9 \pm 0.1$ & $6.8 \pm 0.1$ & ND & $6.3 \pm 0.2$ & ND & ND \\
\hline $\operatorname{TDS}\left(\mathrm{mg} \mathrm{L}^{-1}\right)$ & $473 \pm 4$ & $435 \pm 3$ & 8.0 & $210 \pm 4$ & 51.7 & 55.6 \\
\hline $\mathrm{TS}\left(\mathrm{mg} \mathrm{L}^{-1}\right)$ & $532 \pm 7$ & $500 \pm 9$ & 6.0 & ND & ND & ND \\
\hline Surfactants (mg L $\left.{ }^{-1} \mathrm{MBAS}\right)$ & $15.9 \pm 0$ & $5.1 \pm 0$ & 67.9 & $4.5 \pm 0$ & 11.8 & 71.7 \\
\hline Turbidity (NTU) & $64 \pm 1$ & $5.6 \pm 0.1$ & 91.3 & $0.6 \pm 0.1$ & 89.3 & 99.1 \\
\hline Toxicity factor (TF) & 2 & & & 2 & & \\
\hline
\end{tabular}

$\mathrm{ND}=$ parameter that was not determined.

The total nitrogen parameter of the raw wastewater was $4.8 \mathrm{mg} \mathrm{L}^{-1}$ and met the values required by the federal legislation (CONAMA) No. 430/2011 [65], with a maximum value for the discharge of $20 \mathrm{mg} \cdot \mathrm{L}^{-1}$. After applying the combined process $(\mathrm{C} / \mathrm{F} / \mathrm{S}-\mathrm{MF})$, this parameter reduced $18.8 \%$ in the $\mathrm{C} / \mathrm{F} / \mathrm{S}$ step and $10.3 \%$ in the $\mathrm{MF}$, demonstrating that the proposed process for treating the laundry wastewater was efficient.

The $\mathrm{pH}$ value of the raw wastewater (10.9) was adjusted to 6.4 before the $\mathrm{C} / \mathrm{F} / \mathrm{S}$ treatment, presenting a variation of 0.3 units after the combined process $(\mathrm{C} / \mathrm{F} / \mathrm{S}-\mathrm{MF})$. This result shows that there is no need to adjust the $\mathrm{pH}$ before the discharge of the treated wastewater since it met the values required by the federal legislation (5 to 9) [65].

The surfactant parameter had a total reduction of $71.7 \%$ (wastewater: $15.9 \mathrm{mg} \cdot \mathrm{L}^{-1} \mathrm{MBAS}$ ) and presented a value of $4.5 \mathrm{mg} \cdot \mathrm{L}^{-1}$ MBAS in the permeate after the combined process (C/F/S-MF). Ciabattia et al. [8] obtained a removal of $93 \%$ of anionic surfactants after the total flotation/ ozonation/filtration (activated carbon) and filtration with a PVDF membrane $(20 \mathrm{kDa})$ when treating laundry wastewater $\left(8.78 \mathrm{mg} \cdot \mathrm{L}^{-1}\right.$ of total surfactants).

The TDS value (wastewater: $473 \mathrm{mg} \cdot \mathrm{L}^{-1}$ ) after applying the combined process was $210 \mathrm{mg} \cdot \mathrm{L}^{-1}$. The removal of this parameter was higher in the MF step (51.7\%) in relation to the $\mathrm{C} / \mathrm{F} / \mathrm{S}$ process $(8 \%)$, confirming that the membrane separation process is more efficient for TDS removal. Sumisha et al. [66] studied the treatment of laundry wastewater applying only the UF process with polymeric membranes $(10 \mathrm{kDa})$ and obtained TDS removal of $82 \%\left(\mathrm{TDS}_{\text {initial }} 603.3 \mathrm{mg} \cdot \mathrm{L}^{-1}\right)$ with the operating pressure of 5 bar.

The permeate collected after the C/F/S-MF process was analyzed regarding the free residual chlorine $\left(0.24 \mathrm{mg} \cdot \mathrm{L}^{-1}\right)$ and thermotolerant coliforms $(<1 \mathrm{MPN} / 100 \mathrm{~mL})$, which presented low values, demonstrating the quality of the permeate obtained after the combined treatment.

The value of the toxicity factor (TF) obtained for the raw wastewater and the permeate (MF) was 2, demonstrating that the sample needs to be diluted twice to obtain a reduction in the luminescence of the Vibrio fischeri bacteria inferior to $20 \%$. This result showed that there was no modification of the toxicity of the studied wastewater for this microorganism, meeting the requirements established by state regulations [64] with a TF value of 8 for the discharge of wastewater into water bodies.

Therefore, the COD, total nitrogen, $\mathrm{pH}$, and toxicity parameters analyzed after the combined process (C/F/S-MF) met the values established by the Brazilian state [64] and federal regulations [65] for the discharge of wastewaters into water bodies. The combined treatment was also responsible for the reduction of the other parameters, providing treated water with high quality since it removed $98.4 \%$ of color, $99.1 \%$ of turbidity, $71.7 \%$ of surfactants, and more than $55 \%$ of TDS and TOC of the laundry wastewater.

In general, the most parts of the analyzed parameters of the supernatant from batch 3 (Table 9) presented values lower than the ones from the supernatant obtained from batch 2 (Table 8 ). This fact contributed to the performance of the membrane. The permeation flux of the wastewater in relation to time for $\mathrm{MF}$ at $1.4 \mathrm{bar}$ is presented in Figure 4.

The permeation flux reduced from $203.5 \mathrm{~L} \cdot \mathrm{h}^{-1} \cdot \mathrm{m}^{-2}$ to $155.8 \mathrm{~L} \cdot \mathrm{h}^{-1} \cdot \mathrm{m}^{-2}$ in the first 10 minutes of operation (Figure 4 ), remaining constant after 40 minutes of microfiltration in $146.0 \mathrm{~L} \cdot \mathrm{h}^{-1} \cdot \mathrm{m}^{-2}$. This value for the permeation flux was higher than the one obtained for the same membrane (MF) and pressure (1.4 bar) utilizing the wastewater from the second batch, which started with an initial flux of $201.8 \mathrm{~L} \cdot \mathrm{h}^{-1} \cdot \mathrm{m}^{-2}$ with the stabilization of the permeation flux in $92.2 \mathrm{~L} \cdot \mathrm{h}^{-1} \cdot \mathrm{m}^{-2}$. These results show that the characteristics of the wastewater are relevant to the MF since, for the wastewater containing the least amount of organic matter in the supernatant (batch 3) (TOC $=43.3 \mathrm{mg} \cdot \mathrm{C} \cdot \mathrm{L}^{-1} ; \mathrm{COD}=83 \mathrm{mg} \mathrm{O}_{2} \mathrm{~L}^{-1}$, Table 9), it was obtained the best membrane permeation compared to the wastewater collected in a different period (batch 2: $\mathrm{TOC}=53.1 \mathrm{mg} \cdot \mathrm{C} \cdot \mathrm{L}^{-1} ; \mathrm{COD}=219 \mathrm{mg} \mathrm{O}_{2} \mathrm{~L}^{-1}$, Table 8).

Another parameter that should be considered is the turbidity, which causes the reduction of the permeation flux value because it is an indicator of the number of particles in suspension in the filter medium [17]. In this case, the turbidity value obtained from the supernatant of batch 3 (5.6 NTU) was lower compared to the one from the second batch (11.9 NTU), which confirms the results obtained for the fouling values of $55 \%$ and $60.2 \%$, respectively. 


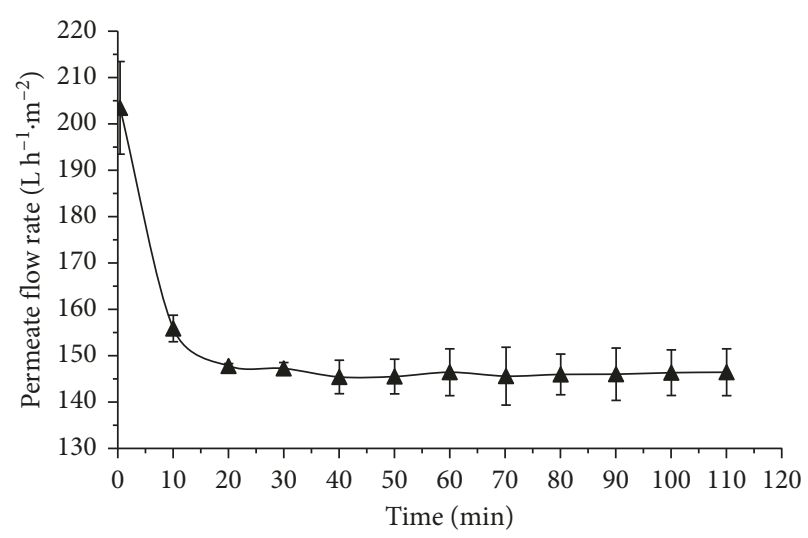

Figure 4: Permeation flux of the wastewater obtained at 1.4 bar for the MF membrane (volumetric flow of $0.5 \mathrm{~L} \cdot \mathrm{min}^{-1}$ ).

These data demonstrate the relevance of the understanding of the wastewater characteristics, as well as the utilization of a pretreatment (C/F/S step) before MF in order to remove the highest quantity of organic matter. It can be justified by the fact that the lower the organic particulate matter in the medium to be filtered, the lower the value for fouling and consequently the higher the operating life of the membrane and permeation flux in the process.

\section{Conclusion}

In the $\mathrm{C} / \mathrm{F} / \mathrm{S}$ process of the laundry wastewater, the utilization of the Tanfloc $\mathrm{POP}^{\circledR}$ natural coagulant demonstrated its efficiency with the dosage of $110 \mathrm{mg} \cdot \mathrm{L}^{-1}$, and a wastewater $\mathrm{pH}$ of 6.4, according to the statistical analyses. The supernatant from the $\mathrm{C} / \mathrm{F} / \mathrm{S}$ process obtained in this experimental condition was submitted to the membrane separation process (MF and UF), resulting in removal efficiencies of the physicochemical parameters (color, total nitrogen, TDS, and turbidity) with an operating pressure of $1.4 \mathrm{bar}$ in a similar way for both membranes but distinct values for the permeation flux. The MF membrane operating at 1.4 bar presented the best performance, with a permeation flux of $92.2 \mathrm{~L} \cdot \mathrm{h}^{-1} \cdot \mathrm{m}^{-2}$, implying in a treatment with a higher volume of wastewater over time. The $\mathrm{C} / \mathrm{F} / \mathrm{S}$ step utilizing the natural coagulant and the separation of components by MF significantly enhanced the quality parameters of the treated wastewater, demonstrating the efficiency of the combined process proposed for treating laundry wastewater.

\section{Data Availability}

No data were used to support this study.

\section{Conflicts of Interest}

The authors declare that they have no conflicts of interest.

\section{Acknowledgments}

The authors gratefully acknowledge the Brazilian research funding agency CAPES (Federal Agency for the Support and
Improvement of Higher Education) for the financial support of this work.

\section{References}

[1] T. L. Silva, A. Ronix, O. Pezoti et al., "Mesoporous activated carbon from industrial laundry sewage sludge: adsorption studies of reactive dye Remazol Brilliant Blue R," Chemical Engineering Journal, vol. 303, pp. 467-476, 2016.

[2] J. Ahmad and H. EL-Dessouky, "Design of a modified low cost treatment system for the recycling and reuse of laundry waste water," Resources, Conservation and Recycling, vol. 52, no. 7, pp. 973-978, 2008.

[3] J. K. Braga and M. B. a Varesche, "Commercial laundry water characterisation," American Journal of Analytical Chemistry, vol. 5, no. 1, pp. 8-16, 2014.

[4] T. Ramcharan and A. Bissessur, "Analysis of linear alkylbenzene sulfonate in laundry wastewater by HPLC-UV and UV-vis spectrophotometry," Journal of Surfactants and Detergents, vol. 19, no. 1, pp. 209-218, 2016.

[5] J. Ge, J. Qu, P. Lei, and H. Liu, "New bipolar electrocoagulation-electroflotation process for the treatment of laundry wastewater," Separation and Purification Technology, vol. 36, no. 1, pp. 33-39, 2004.

[6] F. Janpoor, A. Torabian, and V. Khatibikamal, "Treatment of laundry waste-water by electrocoagulation," Journal of Chemical Technology and Biotechnology, vol. 86, no. 8, pp. 1113-1120, 2011.

[7] S. Šostar-Turk, I. Petrinić, and M. Simonič, "Laundry wastewater treatment using coagulation and membrane filtration," Resources, Conservation and Recycling, vol. 44, no. 2, pp. 185-196, 2005.

[8] I. Ciabattia, F. Cesaro, L. Faralli, E. Fatarella, and F. Tognotti, "Demonstration of a treatment system for purification and reuse of laundry wastewater," Desalination, vol. 245, no. 1-3, pp. 451-459, 2009.

[9] J. Guilbaud, A. Massé, Y. Andrès, F. Combe, and P. Jaouen, "Laundry water recycling in ship by direct nanofiltration with tubular membranes," Resources, Conservation and Recycling, vol. 55, no. 2, pp. 148-154, 2010.

[10] M. Manouchehri and A. Kargari, "Water recovery from laundry wastewater by the cross flow microfiltration process: a strategy for water recycling in residential buildings," Journal of Cleaner Production, vol. 168, pp. 227-238, 2017.

[11] C. Nicolaidis and I. Vyrides, "Closing the water cycle for industrial laundries: an operational performance and technoeconomic evaluation of a full-scale membrane bioreactor system," Resources, Conservation and Recycling, vol. 92, pp. 128-135, 2014.

[12] N. Schouten, L. G. J. van der Ham, G.-J. W. Euverink, and A. B. de Haan, "Selection and evaluation of adsorbents for the removal of anionic surfactants from laundry rinsing water," Water Research, vol. 41, no. 18, pp. 4233-4241, 2007.

[13] E. L. Terechova, G. Zhang, J. Chen, N. A. Sosnina, and F. Yang, "Combined chemical coagulation-flocculation/ ultraviolet photolysis treatment for anionic surfactants in laundry wastewater," Journal of Environmental Chemical Engineering, vol. 2, no. 4, pp. 2111-2119, 2014.

[14] C.-T. Wang, W.-L. Chou, and Y.-M. Kuo, "Removal of COD from laundry wastewater by electrocoagulation/electroflotation," Journal of Hazardous Materials, vol. 164, no. 1, pp. 81-86, 2009.

[15] J. Beltrán-Heredia, J. Sánchez-Martín, and M. C. GómezMuñoz, "New coagulant agents from tannin extracts: 
preliminary optimisation studies," Chemical Engineering Journal, vol. 162, no. 3, pp. 1019-1025, 2010.

[16] J.-D. Lee, S.-H. Lee, M.-H. Jo, P.-K. Park, C.-H. Lee, and J.-W. Kwak, "Effect of coagulation conditions on membrane filtration characteristics in Coagulation-Microfiltration process for water treatment," Environmental Science and Technology, vol. 34, no. 17, pp. 3780-3788, 2000.

[17] H.-C. Kim, X. Shang, J.-H. Huang, and B. A. Dempsey, "Treating laundry waste water: cationic polymers for removal of contaminants and decreased fouling in microfiltration," Journal of Membrane Science, vol. 456, pp. 167-174, 2014.

[18] X. Shang, H.-C. Kim, J.-H. Huang, and B. A. Dempsey, "Coagulation strategies to decrease fouling and increase critical flux and contaminant removal in microfiltration of laundry wastewater," Separation and Purification Technology, vol. 147, pp. 44-50, 2015.

[19] S. M. Mohan, "Use of naturalized coagulants in removing laundry waste surfactant using various unit processes in labscale," Journal of Environmental Management, vol. 136, pp. 103-111, 2014.

[20] A. Y. Zahrim, C. Tizaoui, and N. Hilal, "Coagulation with polymers for nanofiltration pre-treatment of highly concentrated dyes: a review," Desalination, vol. 266, no. 1-3, pp. 1-16, 2011.

[21] S. Y. Choy, K. N. Prasad, T. Y. Wu, M. E. Raghunandan, and R. N. Ramanan, "Performance of conventional starches as natural coagulants for turbidity removal," Ecological Engineering, vol. 94, pp. 352-364, 2016.

[22] N. Graham, F. Gang, G. Fowler, and M. Watts, "Characterisation and coagulation performance of a tannin-based cationic polymer: a preliminary assessment," Colloids and Surfaces A: Physicochemical and Engineering Aspects, vol. 327, no. 1-3, pp. 9-16, 2008.

[23] E. Jurado, M. Fernández-Serrano, J. Núñez Olea, M. Lechuga, J. L. Jiménez, and F. Ríos, "Acute toxicity of alkylpolyglucosides to vibrio fischeri, daphnia magna and microalgae: a comparative study," Bulletin of Environmental Contamination and Toxicology, vol. 88, no. 2, pp. 290-295, 2012.

[24] C. Sun, J. Sun, F. Qiu, W. Li, Z. Chang, and L. Zhang, "The fluorescent property of 3-[(2-hydroxy-1-naphthyl) methylideneamino]benzoic acid and its application as fluorescent chemosensor for $\mathrm{Hg} 2+$ and Al3+ ions," Spectrochimica Acta Part A: Molecular and Biomolecular Spectroscopy, vol. 188, pp. 1-7, 2018.

[25] L. K. Kumawat, N. Mergu, M. Asif, and V. K. Gupta, "Novel synthesized antipyrine derivative based "Naked eye" colorimetric chemosensors for $\mathrm{Al} 3+$ and $\mathrm{Cr} 3+$," Sensors and Actuators B: Chemical, vol. 231, pp. 847-859, 2016.

[26] G. Muthuraman and S. Sasikala, "Removal of turbidity from drinking water using natural coagulants," Journal of Industrial and Engineering Chemistry, vol. 20, no. 4, pp. 1727-1731, 2014.

[27] S. Wang, C. Liu, and Q. Li, "Fouling of microfiltration membranes by organic polymer coagulants and flocculants: controlling factors and mechanisms," Water Research, vol. 45, no. 1, pp. 357-365, 2011.

[28] D. P. Zagklis, P. G. Koutsoukos, and C. A. Paraskeva, “A combined coagulation/flocculation and membrane filtration process for the treatment of paint industry wastewaters," Industrial and Engineering Chemistry Research, vol. 51, no. 47, pp. 15456-15462, 2012.

[29] W. L. Ang, A. W. Mohammad, N. Hilal, and C. P. Leo, "A review on the applicability of integrated/hybrid membrane processes in water treatment and desalination plants," Desalination, vol. 363, pp. 2-18, 2015.
[30] M. Franceschi, A. Girou, A. M. Carro-diaz, M. T. Maurette, and E. Puech-costes, "Optimisation of the coagulationflocculation process of raw water by optimal design method," Water Research, vol. 36, no. 14, pp. 3561-3572, 2002.

[31] A. Alinsafi, M. Khemis, M. N. Pons et al., "Electro-coagulation of reactive textile dyes and textile wastewater," Chemical Engineering and Processing: Process Intensification, vol. 44, no. 4, pp. 461-470, 2005.

[32] L. Liu, B. Li, Z. He, C. Zhang, and D. Fu, "Degradation of bromoamine acid by BDD technology-Use of Doehlert design for optimizing the reaction conditions," Separation and $\mathrm{Pu}$ rification Technology, vol. 146, pp. 15-23, 2015.

[33] S. Hammami, A. Ouejhani, N. Bellakhal, and M. Dachraoui, "Application of Doehlert matrix to determine the optimal conditions of electrochemical treatment of tannery effluents," Journal of Hazardous Materials, vol. 163, no. 1, pp. 251-258, 2009.

[34] S. Hammami, N. Oturan, N. Bellakhal, M. Dachraoui, and M. A. Oturan, "Oxidative degradation of direct orange 61 by electro-Fenton process using a carbon felt electrode: application of the experimental design methodology," Journal of Electroanalytical Chemistry, vol. 610, no. 1, pp. 75-84, 2007.

[35] C. A. Manassero, S. R. Vaudagna, A. M. Sancho, M. C. Añón, and F. Speroni, "Combined high hydrostatic pressure and thermal treatments fully inactivate trypsin inhibitors and lipoxygenase and improve protein solubility and physical stability of calcium-added soymilk," Innovative Food Science and Emerging Technologies, vol. 35, pp. 86-95, 2016.

[36] S. El Hajjaji, C. Cros, and L. Aries, "Optimization of conversion treatment on austenitic stainless steel using experimental designs," International Journal of Metals, vol. 2013, Article ID 757049, 7 pages, 2013.

[37] Y. E. Maguana, N. Elhadiri, M. Bouchdoug, M. Benchanaa, and A. Boussetta, "Optimization of preparation conditions of novel adsorbent from sugar scum using response surface methodology for removal of methylene blue," Journal of Chemistry, vol. 2018, Article ID 2093654, 10 pages, 2018.

[38] S. Ferreira, W. N. L. Dos Santos, C. M. Quintella, B. B. Neto, and J. M. Bosque-Sendra, "Doehlert matrix: a chemometric tool for analytical chemistry?review," Talanta, vol. 63, no. 4, pp. 1061-1067, 2004.

[39] L. F. S. Caldas, C. E. R. De Paula, D. M. Brum, and R. J. Cassella, "Application of a four-variables Doehlert design for the multivariate optimization of copper determination in petroleum-derived insulating oils by GFAAS employing the dilute-and-shot approach," Fuel, vol. 105, pp. 503-511, 2013.

[40] APHA, APHA: Standard Methods for the Examination of Water and Wastewater, Washington, DC, USA, 1998.

[41] APHA, Standard Methods for the Examination of Water and Wastewater, Washington, DC, USA, 2012.

[42] ISO 9308-1: 2014, Water Quality-Enumeration of Escherichia coli and Coliform Bacteria-Part 1: Membrane Filtration Method for Waters with Low Bacterial Background flora, ISO, Geneva, Switzerland, 2014.

[43] ASTM International, ASTM D5176-08 Standard Test Method for Total Chemically Bound Nitrogen in Water by Pyrolysis and Chemiluminescence Detection, West Conshohocken, Vol. 11, West Conshohocken, PA, USA, 2015.

[44] ABNT, NBR-15411-3: Ecotoxicologia Aquática-Determinação do Efeito Inibitório de Amostras Aquosas Sobre a Emissão de Luz de Vibrio Fischeri (Ensaio de Bactéria Luminescente). Parte 3: Método Utilizando Bactérias Liofilizadas, p. 23, ABNT, Rio de Janeiro, Brazil, 2012. 
[45] J. Beltrán-Heredia, J. Sánchez-Martín, and G. Frutos-Blanco, "Schinopsis balansae tannin-based flocculant in removing sodium dodecyl benzene sulfonate," Separation and Purification Technology, vol. 67, no. 3, pp. 295-303, 2009.

[46] A. C. Habert, C. P. Borges, and R. Nobrega, Manual de Operação da Unidade de Bancada de MF/UF, PamMembranas Seletivas Ltd, Rio de Janeiro, Brazil, 2012.

[47] C. Astudillo, J. Parra, S. González, and B. Cancino, "A new parameter for membrane cleaning evaluation," Separation and Purification Technology, vol. 73, no. 2, pp. 286-293, 2010.

[48] L. S. F. Neta, A. C. Habert, and C. P. Borges, "Cerveja Microfiltrada: Processo e Qualidade Beer Microfiltration: Process and Quality," Brazilian Journal of Food Technology, pp. 130-137, 2005.

[49] X. Shi, G. Tal, N. P. Hankins, and V. Gitis, "Fouling and cleaning of ultrafiltration membranes: a review," Journal of Water Process Engineering, vol. 1, pp. 121-138, 2014.

[50] G. Zakrzewska-Trznadel, "Advances in membrane technologies for the treatment of liquid radioactive waste," $D e$ salination, vol. 321, pp. 119-130, 2013.

[51] M. Zeng, A. Soric, and N. Roche, "Calibration of hydrodynamic behavior and biokinetics for TOC removal modeling in biofilm reactors under different hydraulic conditions," Bioresource Technology, vol. 144, pp. 202-209, 2013.

[52] T. P. Delforno, A. G. L. Moura, D. Y. Okada, and M. B. A. Varesche, "Effect of biomass adaptation to the degradation of anionic surfactants in laundry wastewater using EGSB reactors," Bioresource Technology, vol. 154, pp. 114-121, 2014.

[53] P. Lens, G. Zeeman, and G. L. Ettinga, Decentralised Sanitation and Reuse, IWA Publishing, London, UK, 2001.

[54] G. Huang, F. Meng, X. Zheng et al., "Biodegradation behavior of natural organic matter (NOM) in a biological aerated filter (BAF) as a pretreatment for ultrafiltration (UF) of river water," Applied Microbiology and Biotechnology, vol. 90, no. 5, pp. 1795-1803, 2011.

[55] J. Beltrán-Heredia, J. Sánchez-Martín, and C. Gómez-Muñoz, "Performance and characterization of a new tannin-based coagulant," Applied Water Science, vol. 2, no. 3, pp. 199208, 2012.

[56] D. C. Montgomery, Design and Analysis of Experiments, John Wiley and Sons, New York, NY, USA, 4th edition, 1997.

[57] T. Mohammadi, M. Kazemimoghadam, and M. Saadabadi, "Modeling of membrane fouling and flux decline in reverse osmosis during separation of oil in water emulsions," Desalination, vol. 157, no. 1-3, pp. 369-375, 2003.

[58] A. C. Habert, C. P. Borges, and R. Nobrega, Processos de Separação por Membranas, E-Papers, Rio de Janeiro, Brazil, 2006.

[59] Y. S. Li, L. Yan, C. B. Xiang, and L. J. Hong, "Treatment of oily wastewater by organic-inorganic composite tubular ultrafiltration (UF) membranes," Desalination, vol. 196, no. 1-3, pp. 76-83, 2006.

[60] M. Peter-Varbanets, F. Hammes, M. Vital, and W. Pronk, "Stabilization of flux during dead-end ultra-low pressure ultrafiltration," Water Research, vol. 44, no. 12, pp. 3607-3616, 2010.

[61] A. Y. Zahrim, N. Hilal, and C. Tizaoui, “Tubular nanofiltration of highly concentrated C.I. Acid Black 210 dye," Water Science and Technology, vol. 67, no. 4, pp. 901-906, 2013.

[62] X. Sun, C. Wang, Y. Li, W. Wang, and J. Wei, "Treatment of phenolic wastewater by combined UF and NF/RO processes," Desalination, vol. 355, pp. 68-74, 2015.
[63] S. Mozia, M. Janus, P. Brożek et al., "A system coupling hybrid biological method with UV/O3 oxidation and membrane separation for treatment and reuse of industrial laundry wastewater," Environmental Science and Pollution Research, vol. 23, no. 19, pp. 19145-19155, 2016.

[64] Resolução No 70/2009-CEMA, 2009.

[65] Resolução Conama 430/2011, 2011.

[66] A. Sumisha, G. Arthanareeswaran, Y. Lukka Thuyavan, A. F. Ismail, and S. Chakraborty, "Treatment of laundry wastewater using polyethersulfone/polyvinylpyrollidone ultrafiltration membranes," Ecotoxicology and Environmental Safety, vol. 121, pp. 174-179, 2015. 


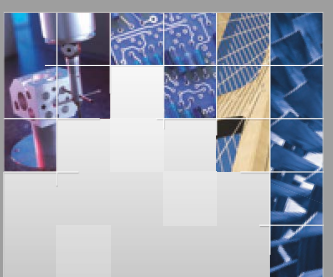

\section{Enfincering}
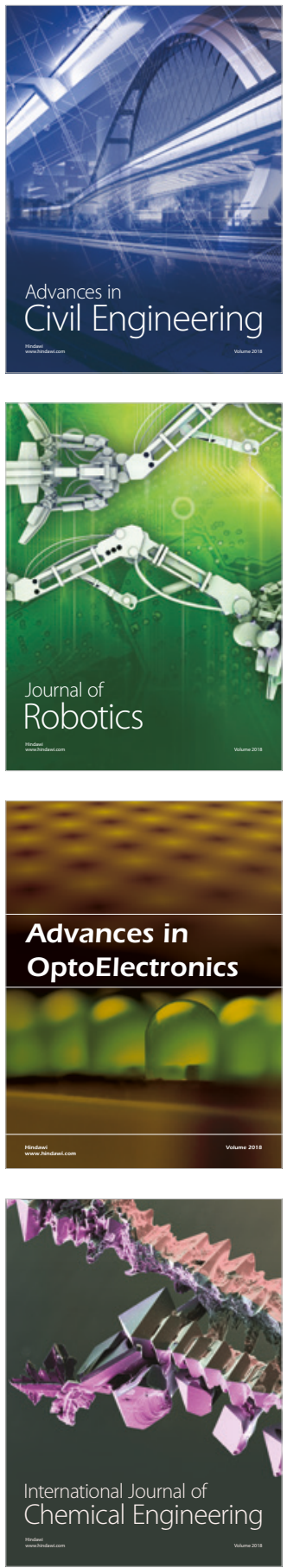

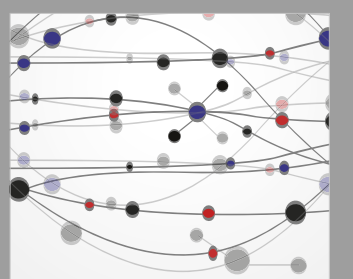

\section{Rotating \\ Machinery}

The Scientific World Journal

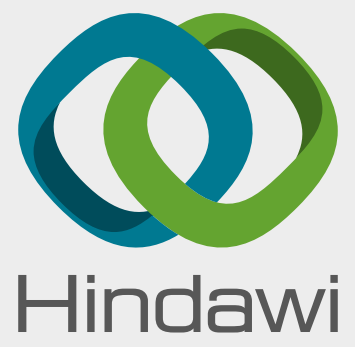

Submit your manuscripts at

www.hindawi.com
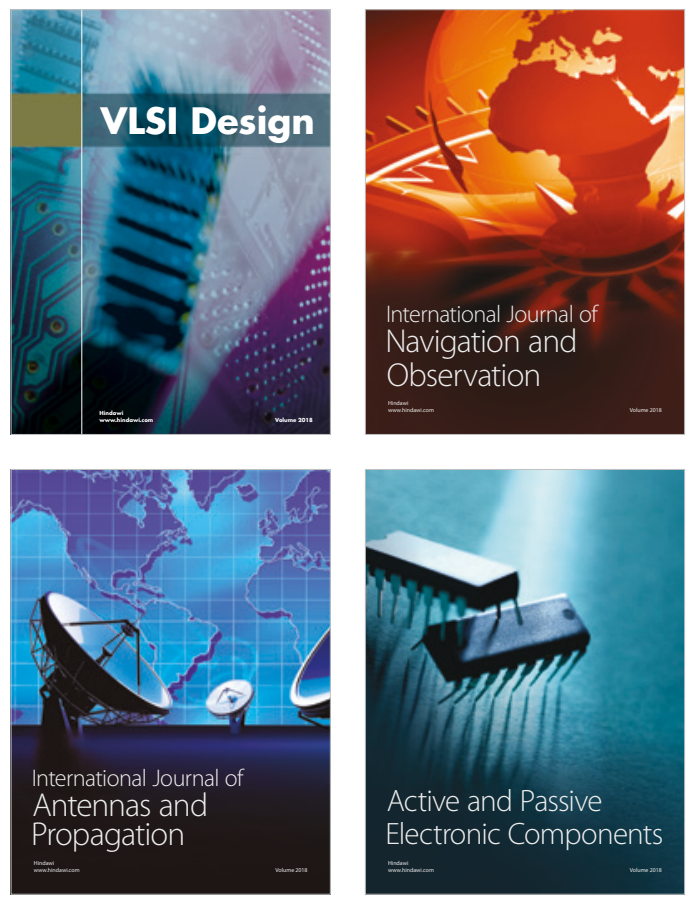
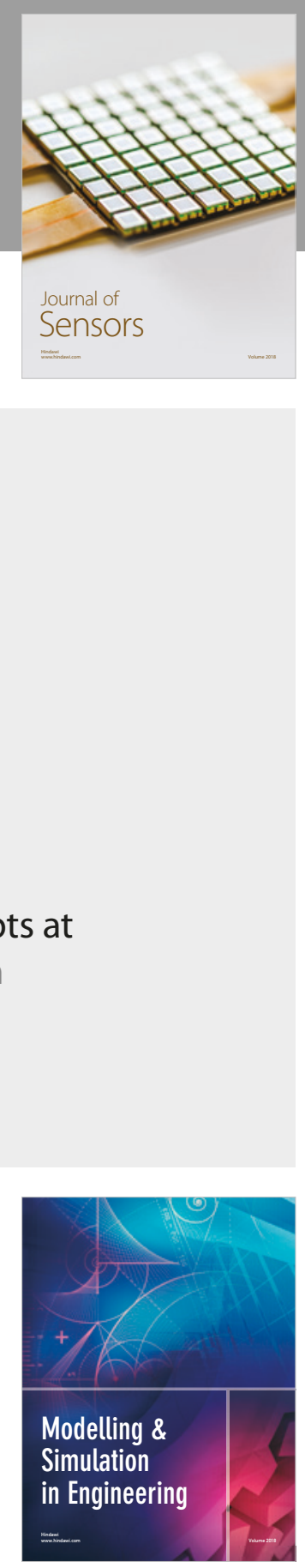

\section{Advances \\ Multimedia}
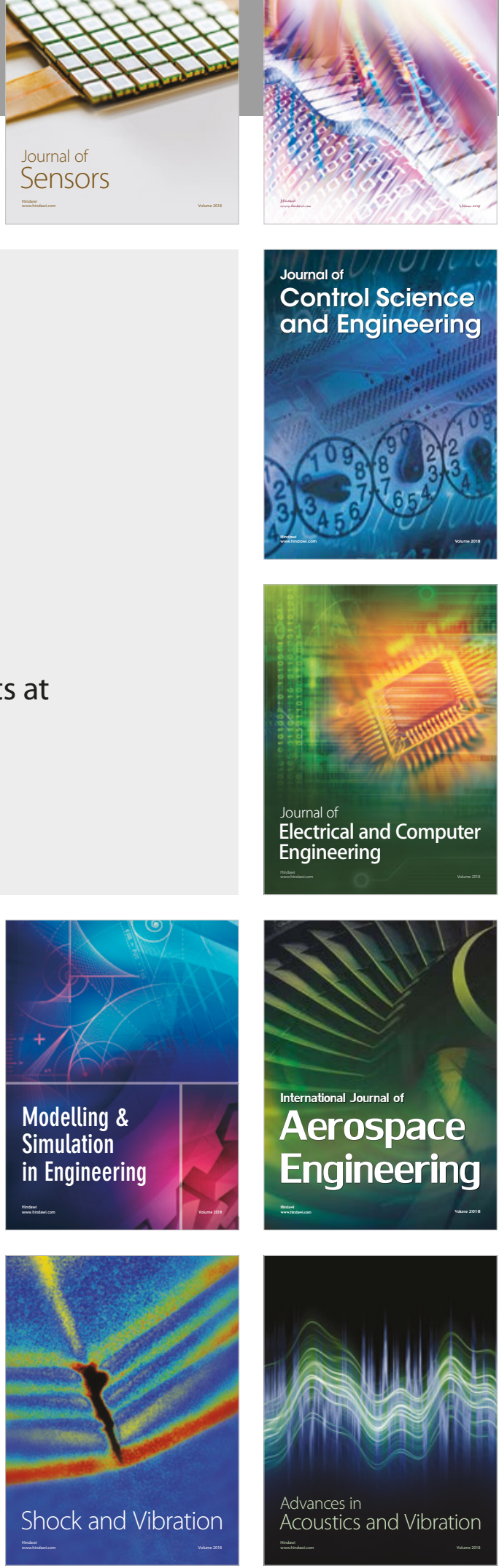